Portland State University

PDXScholar

1990

\title{
Macroinvertebrate drift abundance below Bonneville Dam and its relation to juvenile salmonid food habits
}

William Douglas Muir

Portland State University

Follow this and additional works at: https://pdxscholar.library.pdx.edu/open_access_etds

Part of the Biology Commons

Let us know how access to this document benefits you.

Recommended Citation

Muir, William Douglas, "Macroinvertebrate drift abundance below Bonneville Dam and its relation to juvenile salmonid food habits" (1990). Dissertations and Theses. Paper 4108.

https://doi.org/10.15760/etd.5992

This Thesis is brought to you for free and open access. It has been accepted for inclusion in Dissertations and Theses by an authorized administrator of PDXScholar. Please contact us if we can make this document more accessible: pdxscholar@pdx.edu. 
AN ABSTRACT OF THE THESIS OF William Douglas Muir for the Master of Science in Biology Presented November 6, 1990.

Title: Macroinvertebrate Drift Abundance Below Bonneville Dam and its Relation to Juvenile Salmonid Food Habits.

APPROVED BY THE MEMBERS OF THE THESIS COMMITTEE:

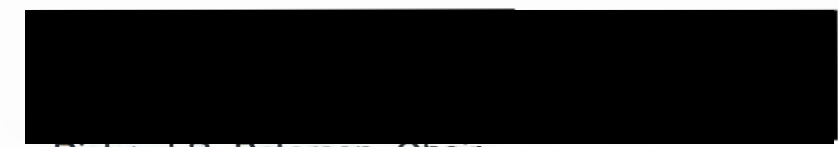

Richard R. Petersen, chair

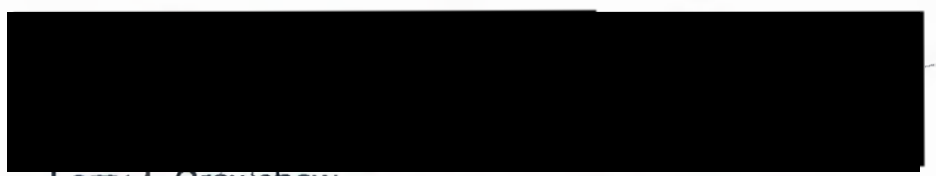

Lamy I. Crawshaw

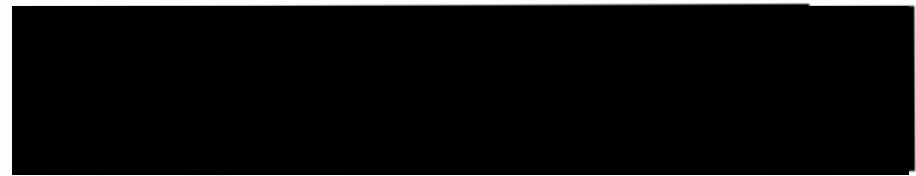

Robert O. Tinnin

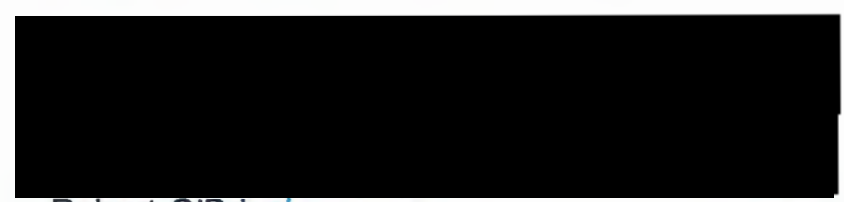

Robert O'Brien

There is a paucity of information concerning the invertebrate food resources available to juvenile salmonids in the Columbia River as they migrate seaward. Construction of mainstream dams has attered the temperature cycle, flow regime, and substrate which indigenous invertebrates were adapted to. Studies on how the macroinvertebrate 
community has adapted to these alterations have been neglected. This study was undertaken to help fill this void.

Macroinvertebrate drift samples were collected over a three year period in the Columbia River downstream from Bonneville Dam. Samples were collected with a D-ring plankton net fished on the bottom for one-half hour. Two sites were sampled; Ives Island (RKM 230), from 1987 through 1989, and Lady Island (RKM 193), in 1988 and 1989.

The drift below Bonneville Dam was sparse and low in diversity. The amphipod

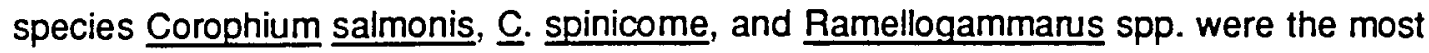
abundant macroinvertebrates collected. Molluscs were also frequently collected, as were Trichoptera, the only aquatic insect commonly found. These taxa are characteristic of macroinvertebrates found in impounded rivers.

The numbers of macroinvertebrates in the drift declined over the three year period for all major taxa except Trichoptera. Furthermore, the amphipod species and mysids were smaller in 1988 than in 1987 . This could result in reduced fecundity which could explain the lower number collected in 1989.

Numbers of all taxa in the drift were low in early April when many salmonid hatcheries release their fish; numbers were generally highest in May. Abundance of Corophium salmonis were significantly correlated with flow in all three years.

These data suggest that the abundance and size of macroinvertebrate species utilized by juvenile salmonids and other resident fish species fluctuates on a yearly basis and could effect juvenile salmonid survival. 
MACROINVERTEBRATE DRIFT ABUNDANCE BELOW BONNEVILLE DAM AND ITS RELATION TO JUVENILE SALMONID FOOD HABITS

\author{
by \\ WILLIAM DOUGLAS MUIR
}

A thesis submitted in partial fulfillment of the

requirements for the degree of

\title{
MASTER OF SCIENCE \\ in \\ BIOLOGY
}

Portland State University

1990 
TO THE OFFICE OF GRADUATE STUDIES:

The members of the Committee approve the thesis of William Douglas Muir presented November 6, 1990.

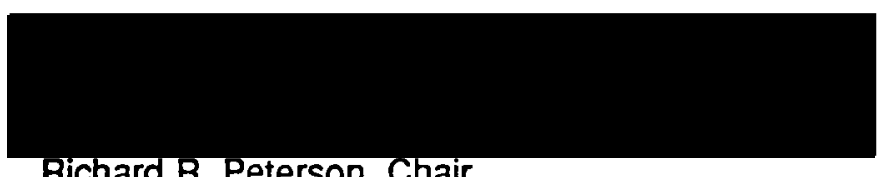

Richard R. Peterson, Chair

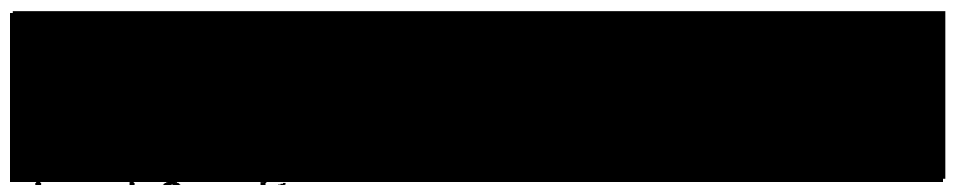

Lamy I. Crawstiaw

C

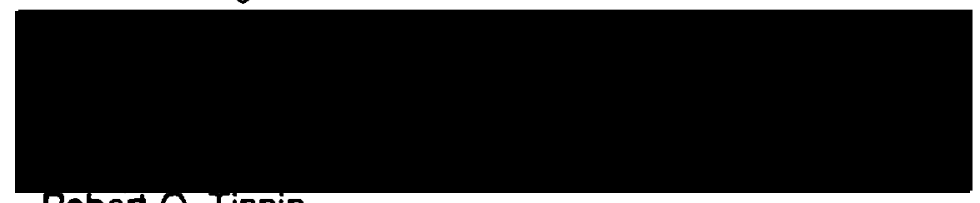

Robert O. Tinnin

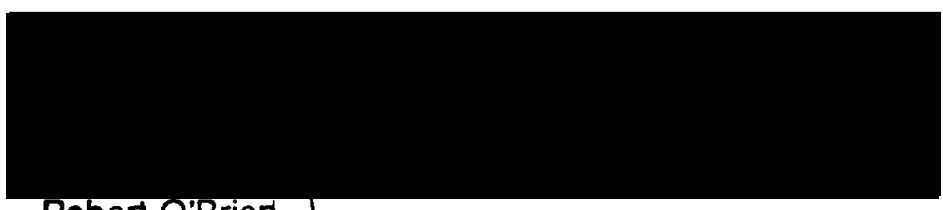

Robert O'Brien

APPROVED:

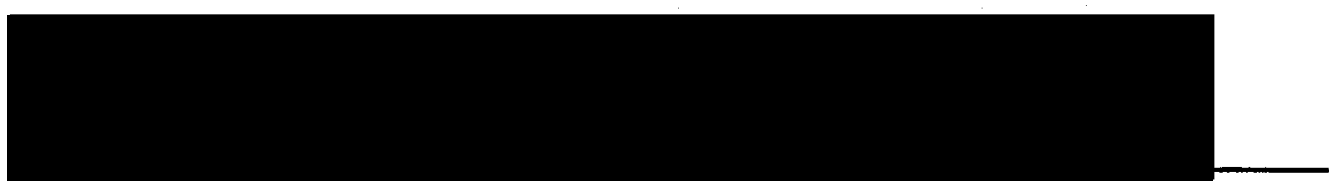

W. Herman laylor, Chair, Deparment of Biology

c. Whiliam Savery, Interim Vice Provost grt Graduate Studies and Research 


\section{ACKNOWLEDGEMENTS}

This study was made possible because of support by the National Marine Fisheries Service (NMFS). I would like to thank several people from NMFS including: George McCabe Jr. and the crew of the R.V. Nerka (Larry Davis, Morris Laird, and Roy Petit) for collecting and preserving samples; Robert Emmett for verifying the identification of invertebrates and reviewing this thesis, and Dr. Albert Giorgi for providing me the opportunity to complete the study and reviewing the thesis.

I would also like to thank Dr. Richard Petersen from Portland State University for his support and helpful comments. 


\section{TABLE OF CONTENTS}

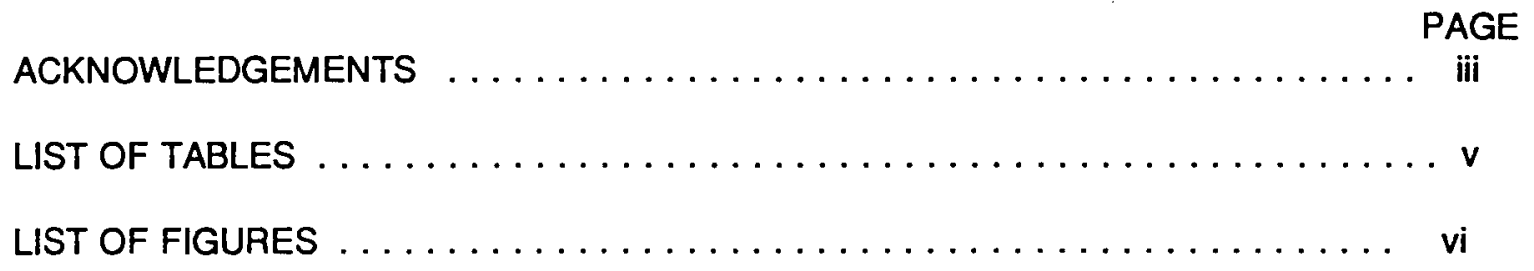

INTRODUCTION $\ldots \ldots \ldots \ldots \ldots \ldots \ldots \ldots \ldots \ldots \ldots \ldots \ldots \ldots \ldots \ldots \ldots \ldots$

METHODS AND MATERIALS $\ldots \ldots \ldots \ldots \ldots \ldots \ldots \ldots \ldots \ldots \ldots$

Study Area $\ldots \ldots \ldots \ldots \ldots \ldots \ldots \ldots \ldots \ldots \ldots \ldots \ldots \ldots \ldots \ldots \ldots \ldots \ldots \ldots$

Sampling Procedure $\ldots \ldots \ldots \ldots \ldots \ldots \ldots \ldots \ldots \ldots \ldots \ldots \ldots \ldots \ldots \ldots$

Temporal Sampling

Diurnal Sampling

Population Characteristics

Data Analysis

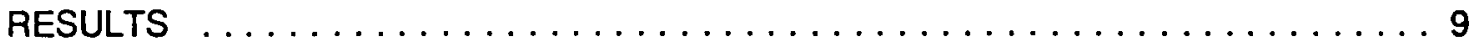

Macroinvertebrate Drift Abundance $\ldots \ldots \ldots \ldots \ldots \ldots \ldots \ldots$

Temporal Abundance

Relationship to Physical Factors

Diurnal Abundance

Yearly Abundance

Population Characteristics

DISCUSSION 30

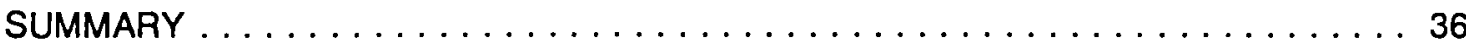

RECOMMENDATIONS $\ldots \ldots \ldots \ldots \ldots \ldots \ldots \ldots \ldots \ldots \ldots \ldots \ldots \ldots \ldots \ldots \ldots \ldots$

LITERATURE CITED $\ldots \ldots \ldots \ldots \ldots \ldots \ldots \ldots \ldots \ldots \ldots \ldots \ldots \ldots$ 


\section{LIST OF TABLES}

TABLE

PAGE

I Macroinvertebrate Drift Sample Schedule Conducted For a Three Year Period in the

Columbia River. Samples Were Collected With a D-ring Plankton Net

Fished on the Bottom and Were One-half Hour in Duration $\ldots \ldots \ldots \ldots 7$

II Numbers of Invertebrates (Unadjusted For Flow) Captured at Two Sites Over a

Three Year Period in the Columbia River. Numbers in Parenthesis

Represent the Number of Samples $\ldots \ldots \ldots \ldots \ldots \ldots \ldots \ldots \ldots 10$

III Numbers of Invertebrates Captured During the 25-26 May Diurnal Conducted at

Ives Island. Numbers Presented are the Total From All Hours Combined

Unadjusted For Flow $\ldots \ldots \ldots \ldots \ldots \ldots \ldots \ldots \ldots \ldots \ldots$ 


\section{LIST OF FIGURES}

FIGURE

1. Study Area Showing Location of Mainstream Dams and Sample Locations Downstream of Bonneville Dam .................. 4

2. The D-ring Type Plankton Net Used to Sample Macroinvertebrates in the Columbia River Downstream of Bonneville Dam; Note the Flow Meter Inserted in the

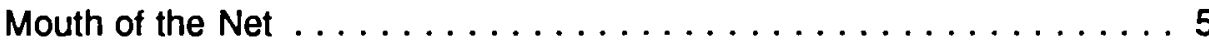

3. The Number of Corophium salmonis (Number/1,000 $\mathrm{m}^{3}$ ) Captured Each Month at Ives Island, $1987-1989 \ldots \ldots \ldots \ldots \ldots \ldots \ldots \ldots \ldots \ldots \ldots$

4. The Number of Corophium spinicorne (Number/1,000 $\mathrm{m}^{3}$ ) Captured Each Month at Ives Island, $1987-1989 \ldots \ldots \ldots \ldots \ldots \ldots \ldots \ldots \ldots \ldots \ldots$

5. The Number of Ramellogammarus spp. (Number/1,000 $\mathrm{m}^{3}$ ) Captured Each Month at Ives Island, 1987-1989

6. The Number of Trichoptera (Number/1,000 $\mathrm{m}^{3}$ ) Captured Each Month at Ives Island, 1987-1989 14

7. The Number of Neomysis mercedis (Number $/ 1,000 \mathrm{~m}^{3}$ ) Captured Each Month at Ives Island, $1987-1989 \ldots \ldots \ldots \ldots \ldots \ldots \ldots \ldots \ldots \ldots \ldots$

8. Mean Monthly River Discharge $\left(\mathrm{m}^{3} / \mathrm{sec}\right.$ in Thousands) at Bonneville Dam From March Through October, $1987-1989 \ldots \ldots \ldots \ldots \ldots \ldots \ldots 17$

9. Mean Monthly Water Temperature $\left({ }^{\circ} \mathrm{C}\right)$ at Bonneville Dam From March Through October, $1987-1989 \ldots \ldots \ldots \ldots \ldots \ldots \ldots \ldots \ldots \ldots \ldots$ 
10. Diurnal Variation in Amphipod Numbers Captured at Ives Island on 25-26 May, 1987 Using a D-ring Plankton Net Fished on the Bottom . . . . . . . 20

11. Mean Annual Catch of Various Macroinvertebrates (April-August) at Ives Island Over a Three Year Period, $1987-1989 \ldots \ldots \ldots \ldots 22$

12. Mean Monthly Length $(\mathrm{mm})$ of Corophium salmonis Captured at Ives Island Over a Three Year Period ......................... 24

13. Mean Monthly Length $(\mathrm{mm})$ of Corophium spinicorne Captured at Ives Island Over a Three Year Period ...................... 25

14. Mean Monthly Length (mm) of Ramellogammarus spp. Captured at Ives Island Over a Three Year Period $\ldots \ldots \ldots \ldots \ldots \ldots$

15. Mean Monthly Length $(\mathrm{mm})$ of Neomysis mercedis Captured at Ives Island Over a Two Year Period . . . . . . . . . . . . . . . . . . . 27

16. A Comparison of Corophium salmonis Sex Composition (Percent of Total) Captured at Ives Island on $25-26$ May, $1987 \ldots \ldots \ldots \ldots \ldots \ldots$

17. A Comparison of Corophium spinicorne Sex Composition (Percent of Total)

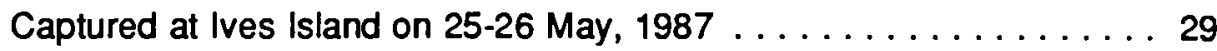




\section{INTRODUCTION}

The Columbia River was historically one of the largest producers of Pacific salmon (Oncorhynchus spp.) in the world (Chaney and Perry 1976). Runs have declined in recent years to the point that some stocks have recently been petitioned for listing under the endangered species act.

Dams on the Columbia and Snake Rivers have altered the food resources available for migrating juvenile salmonids (Ebel et al. 1989; Muir an Emmett 1988; Robeck et al. 1954; Rondorf et al. 1990). The reservoirs they created have increased the mortality of seaward migrating salmonid smolts partially due to increased travel time through reservoirs (Ebel 1977; Raymond 1979). Energy reserves are often depleted during seaward migration; thus a prolonged migration further increases the energy demand on smolts (Rondorf et al. 1985). To help offset this depletion of energy reserves, migrating smolts actively feed during their seaward migration. Therefore, food availability in the reservoirs and lower Columbia River could play a critical role in smolt survival.

Every year, in addition to the unknown number of wild salmonid smolts, approximately 200 million smolts are released from state and federal hatcheries into the Columbia River basin (personal communication, Robert Emmett, National Marine Fisheries Service, Hammond, Oregon). These fish eat a variety of prey during their outmigration. However, during the

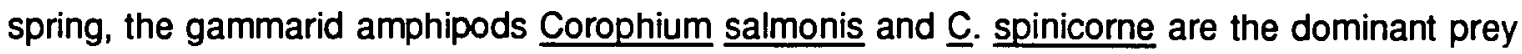
for all of the juvenile salmonid species in the Columbia River estuary (McCabe et al. 1983; 1986) and at Bonneville Dam (Muir and Emmett 1987). Corophium spp. are also important prey for salmonids in the John Day reservoir (Kolak and Rondorf (1987) and at Lower Granite Dam on the Snake River (personnel observation). It is also the major prey of juvenile white sturgeon, Acipenser transmontanus, a commercially and recreationally important fish species in 
the lower Columbia River (Muir et al. 1988). Despite their importance as a food base to support these fish, little is known about the ecology of these species in the Columbia River. Impoundment has been found to decrease diel and seasonal temperature ranges of rivers, due to the buffering effects of large volumes of water (Petts 1984; Ebel et al. 1989). This lowers biotic diversity and often leads to domination of the benthic invertebrate community by collectors (filtering/suspension feeders). Aquatic insects which rely on thermal cues to trigger metamorphosis are often eliminated after impoundment (Petts 1984). Spence and Hynes (1971) observed that the effects of impoundment were similar to mild organic pollution which reduces fish and invertebrate species diversity making them similar to lower order streams (downstream areas). River regulation also reduces water velocities which increases sedimentation. The importance of amphipod and mollusc species frequently increase in regulated rivers (Petts 1984) and this appears to be true for the Columbia River (Muir and Emmett 1988; Robeck et al. 1954).

Although construction of dams on the Columbia and Snake Rivers has radically altered the hydrology and biological communities of these rivers, relatively little research has been conducted to identify the ecological changes that have resulted. The purpose of this investigation was to identify what and when macroinvertebrate prey items were available to fish in the lower Columbia River. The study was conducted just downstream from Bonneville Dam, the lowermost dam on the Columbia River system. The primary objectives were to document macroinvertebrate drift: 1) species composition and relative abundance; 2) seasonal and yearly variations in abundance; and 3) relationships with flow and temperature. 


\section{METHODS AND MATERIALS}

\section{STUDY AREA}

Epibenthic samples for this study were collected in conjunction with a study of white sturgeon egg and larval abundance in the Columbia River conducted by the National Marine Fisheries Service (NMFS) and the Washington Department of Fisheries (Nigro 1988; 1989). Samples were collected at two sites below Bonneville Dam near Ives Island (river kilometer RKM 230) and Lady Island (RKM 193) (Figure 1).

Bonneville Dam (RKM 233) is the lowermost dam on the Columbia River and its impoundment, Bonneville reservoir, is the widest and shallowest reservoir on the Columbia system (Ebel et al. 1989). Columbia River impoundments are river-run reservoirs with relatively fast flushing times; for example, Bonneville reservoir has a flushing time of 1.5 days (Ebel et al. 1989). These reservoirs have little or no thermal stratification; highest water temperatures occur in August-September (near $22^{\circ} \mathrm{C}$ ) and are lowest in January-February (near $2^{\circ} \mathrm{C}$ ).

The Ives Island site is three to four $\mathrm{km}$ downstream from Bonneville Dam in a high flow area and has large rock and cobble for substrate. The Lady Island site is $32 \mathrm{~km}$ downstream from Bonneville Dam and has a course sand substrate. Depth at the Ives Island site ranged from 3 to $7 \mathrm{~m}$ and at the Lady Island site from 16 to $21 \mathrm{~m}$.

\section{SAMPLING PROCEDURE}

Macroinvertebrate samples were collected from an anchored $12.2 \mathrm{~m}$ research vessel using a weighted $\mathrm{D}$-ring plankton net fished on the bottom (Figure 2). The net was $0.8 \mathrm{~m}$ wide at the bottom of the mouth opening and constructed of $1.6 \mathrm{~mm}$ nylon marquisette netting. The volume of water sampled was measured by a digital flow meter (General Oceans Model 2030) 


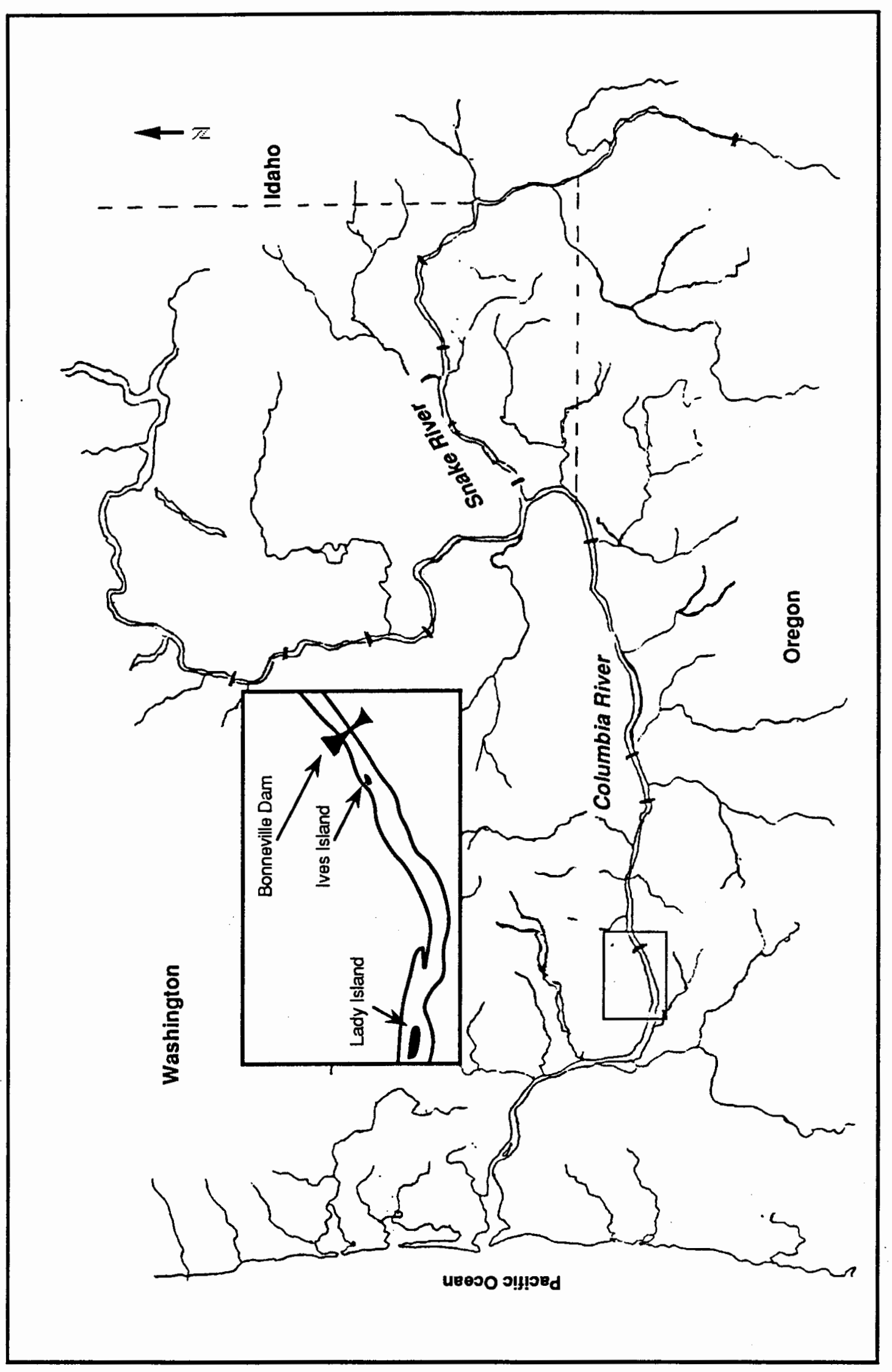




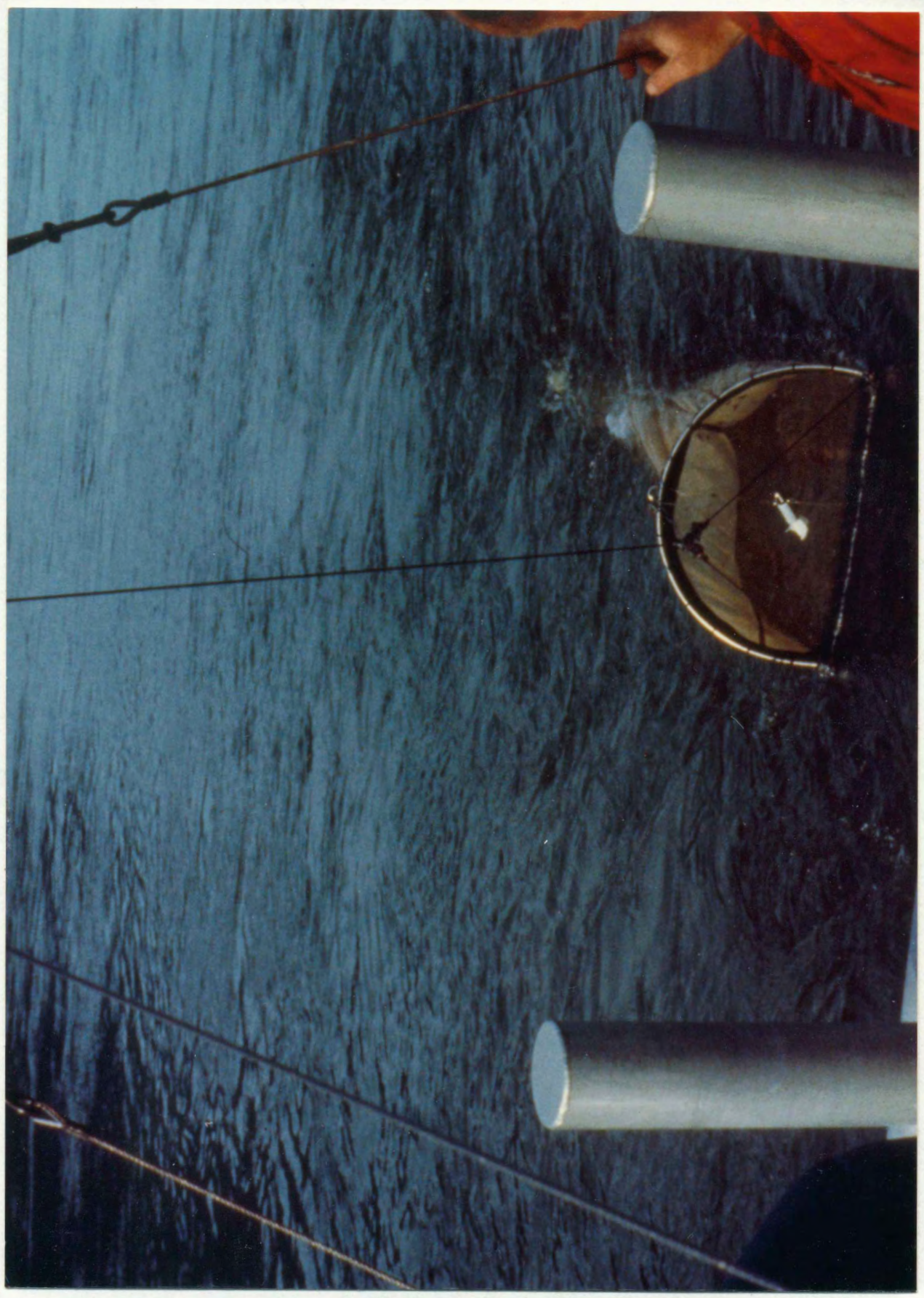

ฮั)

है

Ф

등

क ह

홍

힐

.

임

ह

을 흔

है ह

응

$8=$

ङ

ฮ 음

을

ㄹ

즘

\%

之

윤

ช

E

월 을 
which was suspended in the mouth of the net. Invertebrate catches were standardized by converting the actual number captured to number $/ 1,000 \mathrm{~m}^{3}$. After removal, the net contents were preserved immediately in jars with $4 \%$ buffered formaldehyde solution; they were later transferred to $70 \%$ alcohol. Invertebrates were removed from the drift litter, identified to the lowest practical taxon, and enumerated. During 1987, the presence of molluscs and cladocerans were noted but not enumerated.

Daily river flow $\left(1,000 \mathrm{~m}^{3} / \mathrm{second}\right)$ and water temperature data were obtained from the United States Army Corps of Engineers office in Portland, Oregon.

\section{Temporal Sampling}

Samples were collected at Ives Island over three years (1987-1989) and at Lady Island for two years (1988-1989). Samples were collected between 0800 and $1700 \mathrm{~h}$ and were one half hour in duration. Most of the samples were paired and were usually collected simultaneously.

At Ives Island, sample collection began in late March of each year. During 1987, samples were taken on a biweekly schedule through November. During 1988 and 1989, samples were collected weekly or biweekly into August (Table I).

At Lady Island, samples were collected weekly during 1988 from 10 May through 5 July and biweekly in 1989 from 9 May to 6 July (Table 1). This site was not sampled during 1987.

\section{Diurnal Sampling}

Diurnal samples were collected at the Ives Island site on 25-26 May, 1988 starting at 1843 and ending at 0630 the following morning. Samples were collected in the same manner as those collected during temporal sampling except were one hour in duration. Samples collected during daylight (before dusk and after dawn) were treated as replicates $(n=3)$ and combined and compared with those collected during darkness $(n=7)$. 
MACROINVERTEBRATE DRIET SAMPLE SCHEDULE CONDUCTED FOR A THREE YEAR PERIOD IN THE COLUMBIA RIVER. SAMPLES WERE COLLECTED WITH

A D-RING PLANKTON NET FISHED ON THE BOTTOM AND WERE ONE-HALE HOUR IN DURATION.

\begin{tabular}{|c|c|c|c|c|c|}
\hline \multirow[b]{2}{*}{ Month } & 1987 & \multicolumn{2}{|c|}{1988} & \multicolumn{2}{|c|}{1989} \\
\hline & RKM 230 & RKM 193 & RKM 230 & RKM 193 & RKM 230 \\
\hline March & biweekly & $---\infty$ & biweekly & --- & ---- \\
\hline April & biweekly & 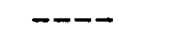 & biweekly & --- & weekly \\
\hline May & biweekly & weekly & weekly & biweekly & weekly \\
\hline June & biweekly & weekly & weekly & biweekly & weekly \\
\hline July & biweekly & weekly & biweekly & biweekly & biweekly \\
\hline August & biweekly & --- & biweekly & $-\infty$ & biweekly \\
\hline September & biweekly & $-\infty$ & ---- & ---- & ---- \\
\hline October & biweekly & ---- & ---- & --- & ---- \\
\hline November & biweekly & ---- & ---- & ---- & --ー- \\
\hline
\end{tabular}


All amphipods were identified to species and measured from the tip of the rostrum to the tip of the telson (to the nearest $0.1 \mathrm{~mm}$ ) using a dissecting microscope with a calibrated eyepiece micrometer. Amphipod age structure was examined by calculating a mean size for each month for each species to look for the development of age classes. Corophium spp. were also sexed (those $>3.0 \mathrm{~mm}$ ) on the basis of morphological differences in the second antennae. The presence and number of eggs in the brood pouch of amphipod females were also noted. Aquatic insects were identified to order and life stage. Mysids were identified to species.

\section{Data Analysis}

Differences in abundance between years, size, and sex ratio were evaluated for each of the major invertebrate taxa using a F-test for equality of variances and Students T-test for differences between means. When unequal variances were detected, Satterthwaite's approximation described in Snedecor and Cochran (1980) was used.

The relationship between the standardized number (Number $/ 1,000 \mathrm{~m}^{3}$ ) of each of the major invertebrate taxa, river flow (mean monthly discharge at Bonneville Dam), and water temperature (mean monthly water temperature at Bonneville Dam) was identified using the nonparametric Spearman's rank correlation coefficient for each of the major invertebrate taxa each year and for all three years combined. 


\section{RESULTS \\ MACROINVERTEBRATE DRIFT ABUNDANCE}

The macroinvertebrate drift below Bonneville Dam was composed of relatively few taxa (Table II). Amphipods (several species) were the most abundant invertebrates in the samples at both Ives and Lady Islands. The Asian clam, Corbicula manilensis, and gastropods (Fisherola and Hydrobiidae) were also abundant, especially at the Ives Island site. Trichoptera were the only aquatic insects commonly found. Almost all of the Trichoptera captured were from the family Hydropsychadae (Cheumatopsyche spp.), a free living, net spinning caddisfly common in large rivers. Other aquatic and terrestrial insect orders were found occasionally, but in small numbers. Smaller zooplankton species (cladocerans and copepods) were occasionally captured in high numbers, but infrequently. However, the large mesh size $(1.6 \mathrm{~mm})$ probably allowed these taxa to pass through and were not sampled effectively.

\section{Temporal Abundance}

Because of the small number of samples collected each month and between sample variation, statistical comparisons between months were not attempted. However, macroinvertebrate drift abundance appeared to change seasonally. The number of macroinvertebrates in the drift were typically low in March and began increasing in late April. Catches of the amphipod species Corophium salmonis were highest in May and June during all three years (Figure 3). Catches of Corophium spinicorne, Ramellogammanus spp., and Trichoptera were also higher during this time period, although higher numbers were captured in September and October of 1987 (Figures 4, 5 and 6). Sampling was terminated during August in 1988 and 1989. The mysid Neomysis mercedis increased in abundance during late summer and fall (Figure 7). 
NUMBERS OF INVERTEBRATES (UNADJUSTED FOR FLOW) CAPTURED AT TWO SITES OVER A THREE YEAR PERIOD IN THE COLUMBIA RIVER. NUMBERS IN PARENTHESIS REPRESENT THE NUMBER OF SAMPLES.

\begin{tabular}{|c|c|c|c|c|c|}
\hline & $\begin{array}{c}1987 \\
\text { RKM } 230 \\
(34)\end{array}$ & $\begin{array}{c}1 \\
\text { RKM } 193 \\
(21)^{1}\end{array}$ & $\begin{array}{l}8 \\
\text { RKM } 230 \\
(31)\end{array}$ & $\operatorname{RKM~}_{(8)}^{193}$ & $\begin{array}{l}\text { RKM } 230 \\
(29)\end{array}$ \\
\hline Phylum: Nemertea & 1 & & & & \\
\hline Phylum: Nematoda & 5 & & 1 & & 1 \\
\hline $\begin{aligned} \text { Phylum: } & \text { Annelida } \\
\text { Class: } & \text { Polychaeta }\end{aligned}$ & & & & & \\
\hline Neanthes limnicola & & & & & 3 \\
\hline Class: Clitellata & & & & & \\
\hline Subclass: Oligochaeta & 6 & 2 & 9 & 1 & 22 \\
\hline $\begin{aligned} \text { Phylum: } & \text { Mollusca } \\
\text { Class: } & \text { Gastropoda }\end{aligned}$ & & & & & \\
\hline $\begin{array}{l}\text { Hydrobiidae } \\
\text { Fisherola }\end{array}$ & $\begin{array}{r}a \\
14\end{array}$ & 2 & $\begin{array}{r}8 \\
80\end{array}$ & & $\begin{array}{l}129 \\
118\end{array}$ \\
\hline $\begin{array}{l}\text { Class: Bivalvia } \\
\text { Order: Heterodonta } \\
\text { Family: Corbiculidae }\end{array}$ & & & & & \\
\hline Corbicula manilensis & a & 59 & 156 & & 94 \\
\hline $\begin{aligned} \text { Phylum: } & \text { Arthropoda } \\
\text { Class: } & \text { Crustacea } \\
\text { Order: } & \text { Mysidacea }\end{aligned}$ & & & & & \\
\hline$\frac{\text { Neomysis }}{\text { order: cladocera }}$ & 101 & & 31 & & 12 \\
\hline $\begin{array}{l}\text { Daphnia spp. } \\
\text { Lepidoptera spp. }\end{array}$ & $\begin{array}{l}a \\
a\end{array}$ & 1 & 1 & & \\
\hline $\begin{array}{ll}\text { Order: } & \text { Calanoida } \\
\text { Order: } & \text { Amphipoda }\end{array}$ & & & 93 & & \\
\hline Ramel logammarus spp. & 211 & 39 & 153 & 8 & 193 \\
\hline Corophium salmonis & 239 & 76 & 74 & 20 & 43 \\
\hline Corophium spinicorne & 297 & 173 & 260 & 16 & 70 \\
\hline Order: Decapoda & & & & & \\
\hline Pacifasticus spp. & 1 & & 5 & & 7 \\
\hline Class: Insecta & & & & & \\
\hline Ephemeroptera & 1 & 8 & 2 & 1 & 7 \\
\hline Trichoptera & 78 & 24 & 187 & 5 & 171 \\
\hline $\begin{array}{l}\text { Diptera } \\
\text { Coleoptera }\end{array}$ & 15 & 8 & $\begin{array}{l}2 \\
2\end{array}$ & & 2 \\
\hline Odonata & 2 & 1 & & & \\
\hline Hymenoptera & & 3 & 1 & & 1 \\
\hline Homoptera & 2 & 1 & 2 & 1 & 2 \\
\hline Hemiptera & & 1 & 3 & & \\
\hline $\begin{array}{l}\text { Order: Plecoptera } \\
\text { Class: Arachnida }\end{array}$ & $\begin{array}{l}1 \\
1\end{array}$ & & & & \\
\hline
\end{tabular}

a) not enumerated 


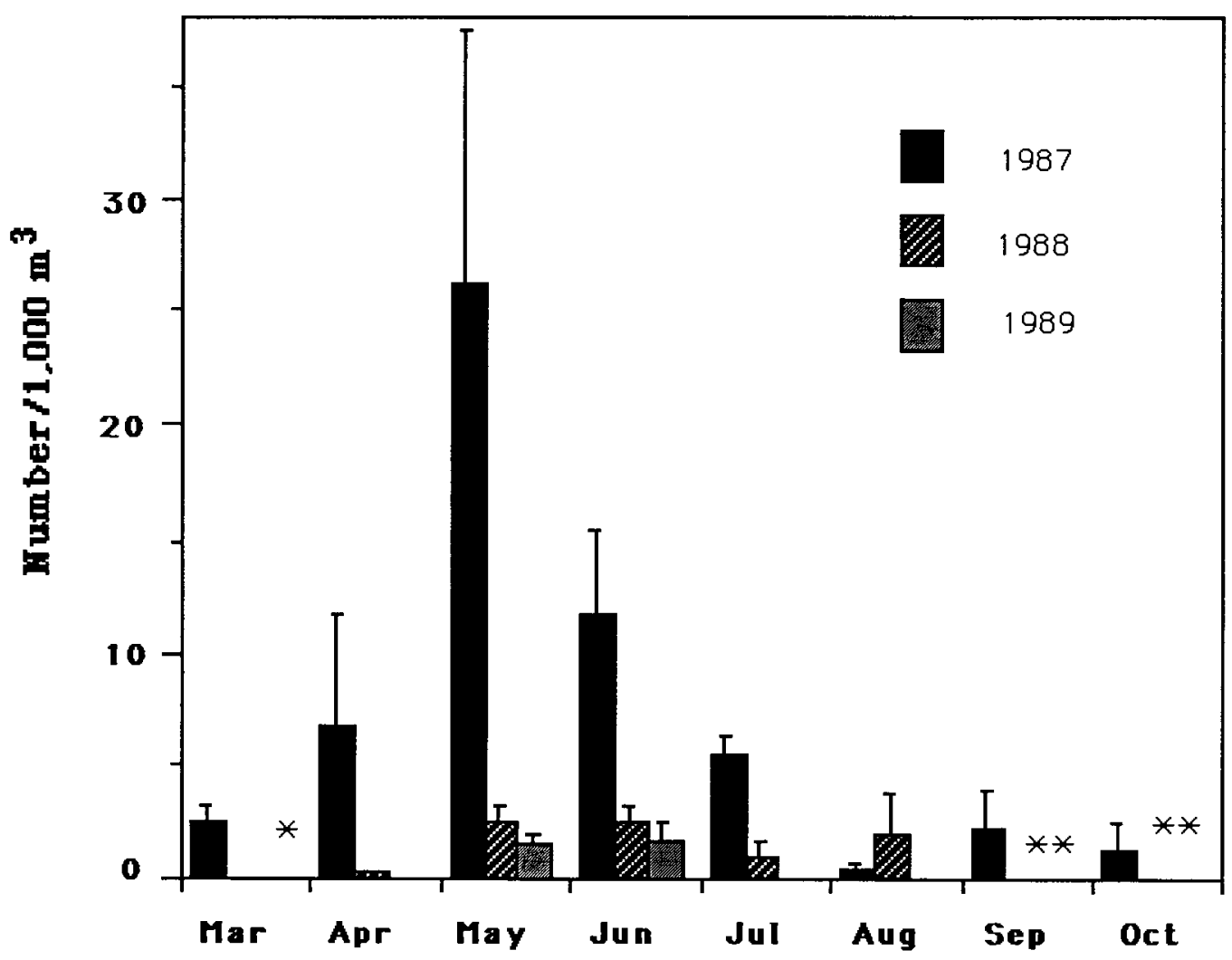

Figure 3 . The number of Corophium salmonis (number $/ 1,000 \mathrm{~m}^{3}$ ) captured each month at Ives Island, 1987-1989. Error bars represent standard errors; asterisks denote no samples collected that month. 


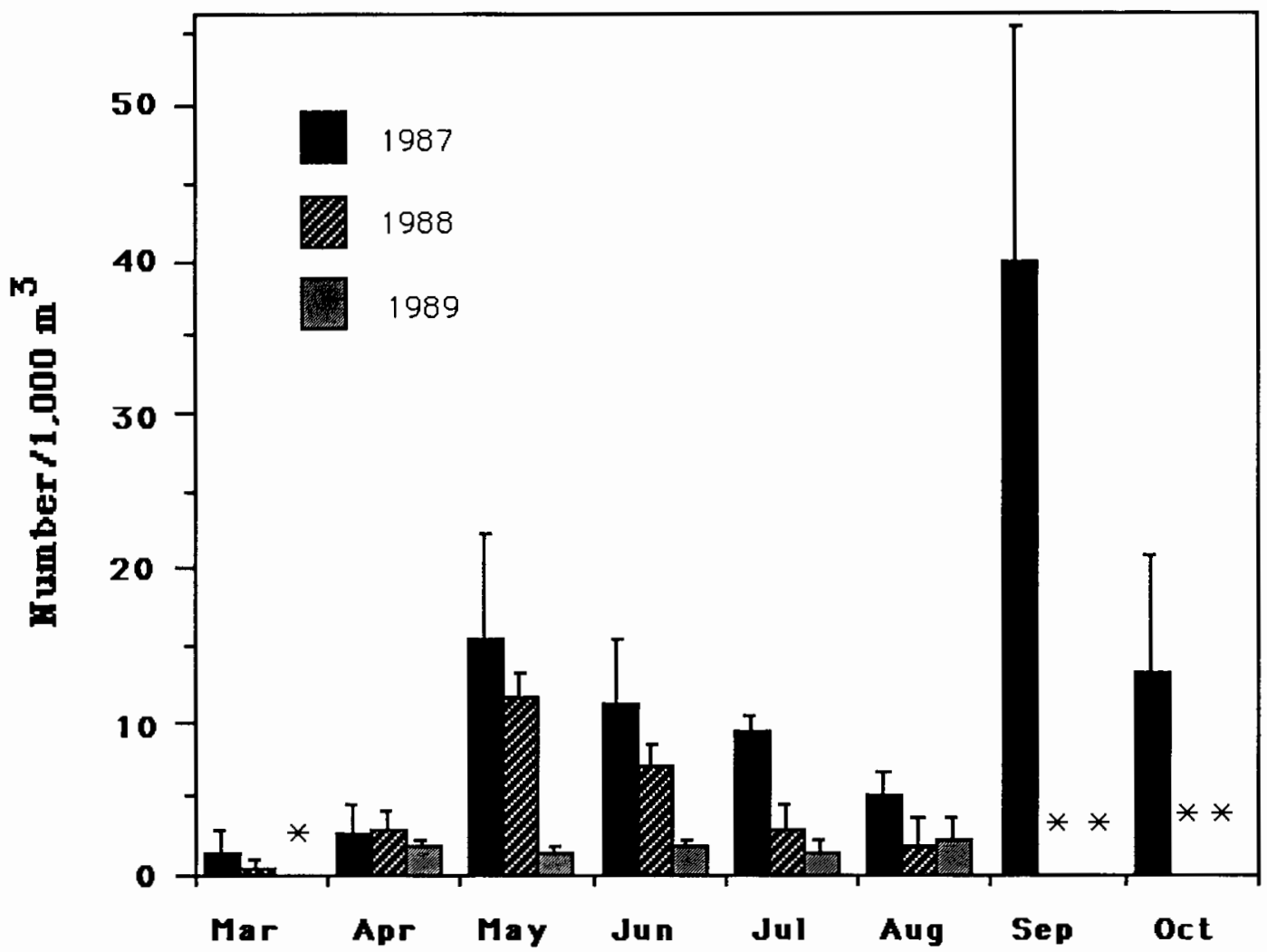

Figure 4. The number of Corophium spinicorne (number $/ 1,000 \mathrm{~m}^{3}$ ) captured each month at Ives Island, 1987-1989. Error bars represent standard errors; asterisks denote no samples collected that month. 


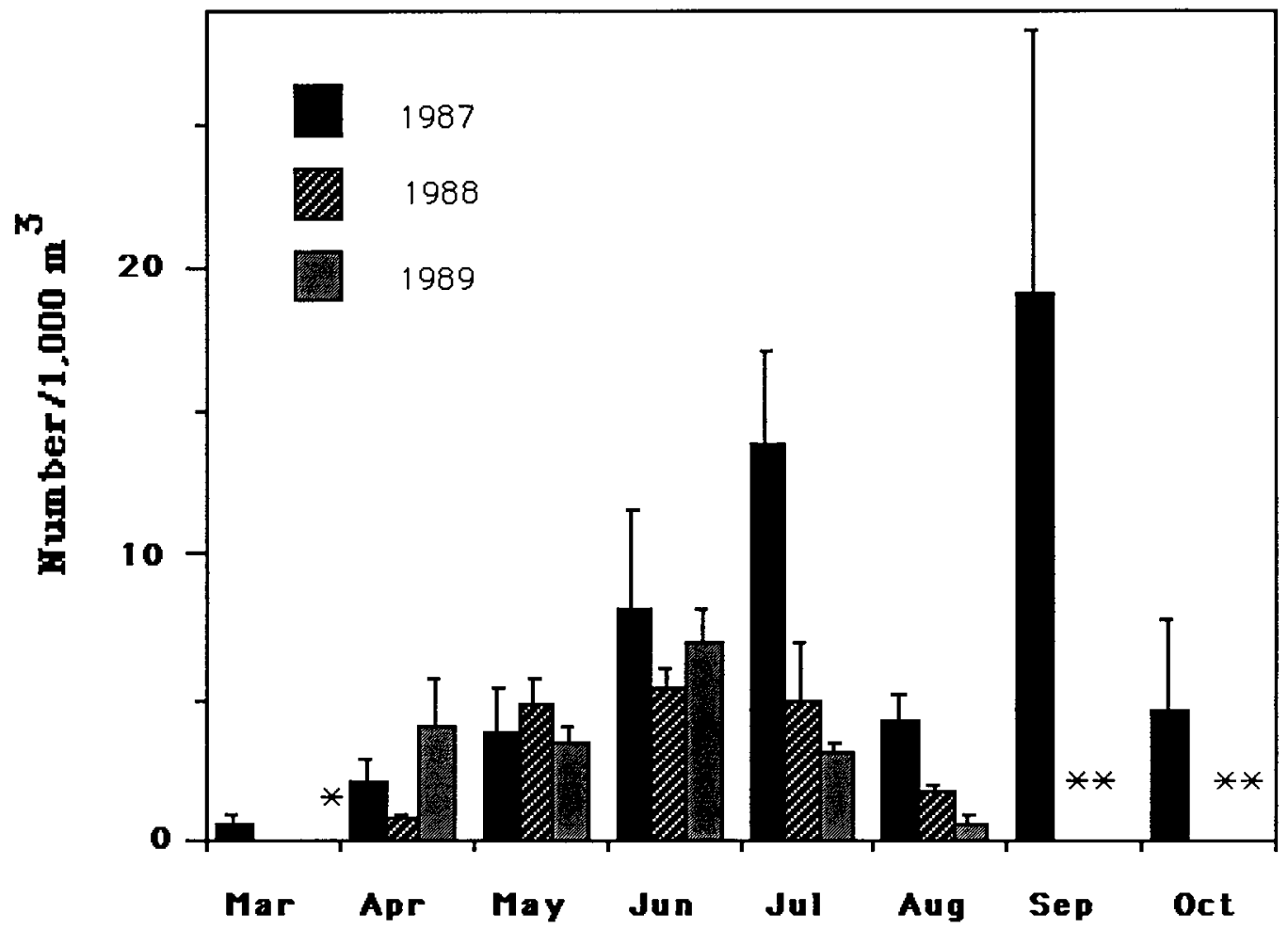

Figure 5 . The number of Ramellogammarus spp. (number $/ 1,000 \mathrm{~m}^{3}$ ) captured each month at Ives Island, 1987-1989. Error bars represent standard errors; asterisks denote no samples collected that month. 


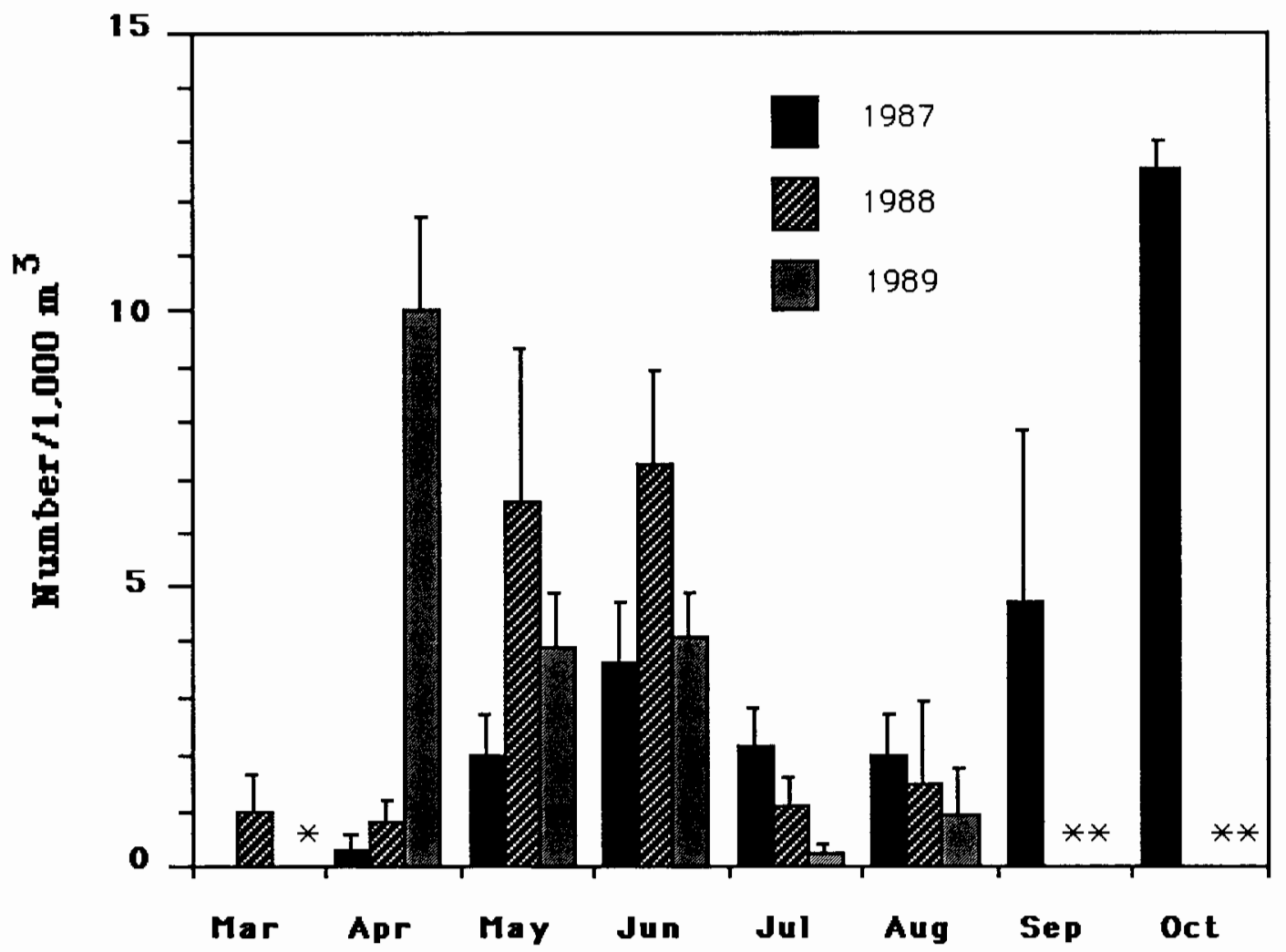

Fiqure 6. The number of Trichoptera (number $/ 1,000 \mathrm{~m}^{3}$ ) captured each month at Ives Island, 1987-1989. Error bars represent standard errors; asterisks denote no samples collected that month. 


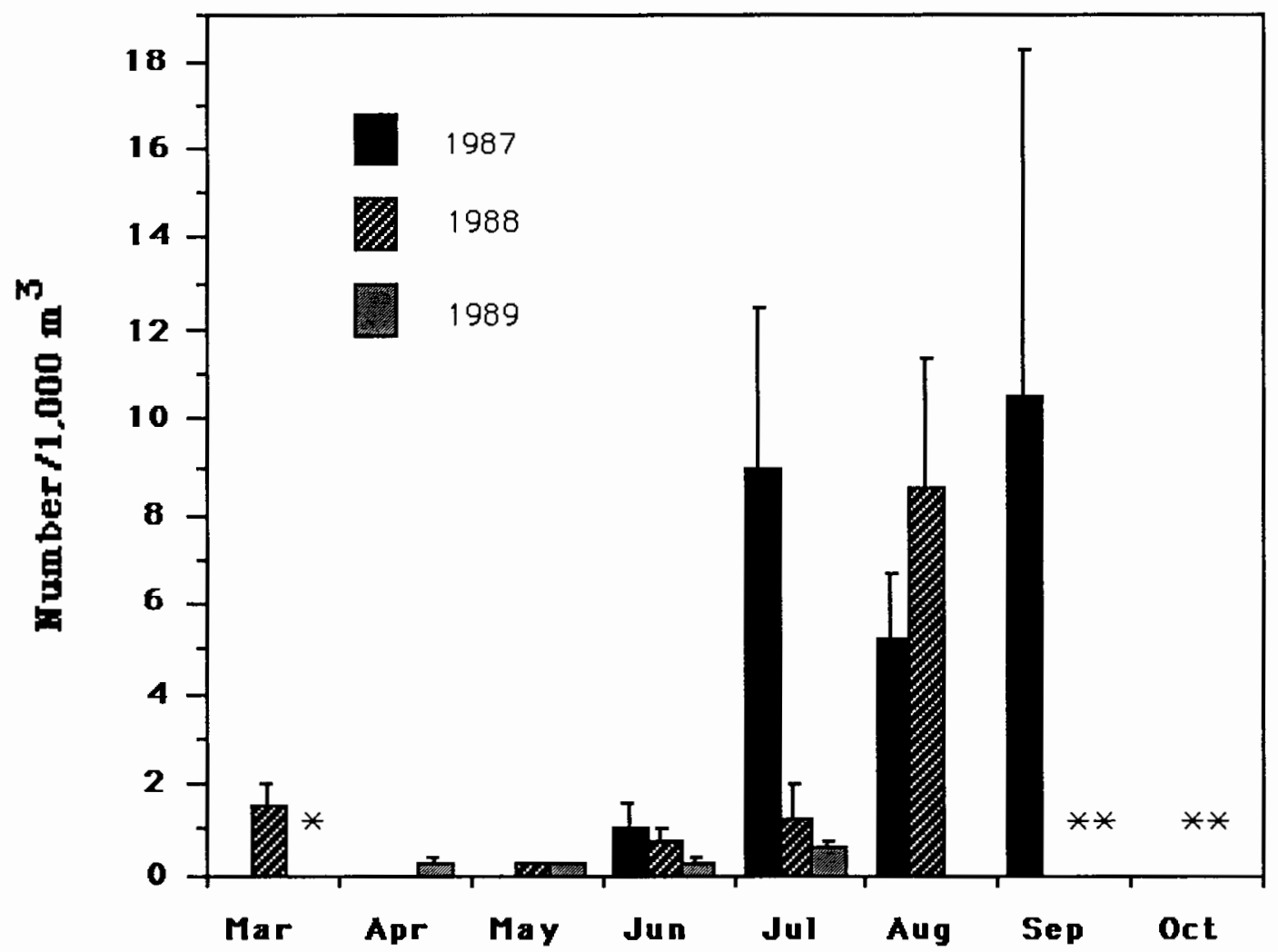

Figure 7. The number of Neomysis mercedis (number $/ 1,000 \mathrm{~m}^{3}$ ) captured each month at Ives Island, 1987-1989. Error bars represent standard errors; asterisks denote no samples collected that month. 
Discharge at Bonneville Dam was highest from April through June, and peaked in May, during all three years (Figure 8). There was a significant correlation $(r=0.2607,91 \mathrm{df}, \mathrm{P}<$ 0.01) between the abundance of $\underline{\underline{C}}$. salmonis and discharge for all three years combined and for each year; $1987(r=0.6181,31 d f, P<0.01), 1988(r=0.4004,29 d f, P<0.05)$, and 1989, $(r=0.6373,27 d f, P<0.01)$. There was significant correlation $(r=0.6604,29 d f, P<0.01)$ between the abundance of $\underline{\mathrm{C}}$. spinicorne and discharge during 1988 but none for 1987 or 1989. There was no consistent relationship between discharge and abundance for the other invertebrate taxa.

Water temperature increased from March through August-September for each of the three years (Figure 9). Mean monthly water temperature and mean number $/ 1,000 \mathrm{~m}^{3}$ of Ramellogammarus spp. was significant $(r=0.3615,91 \mathrm{df}, \mathrm{P}<0.01)$ for the three years combined. Catches were also correlated with water temperature for $1987(r=0.4806,31 \mathrm{df}, \mathrm{P}$ $<0.01)$ and $1988(r=0.4139,29 d f, P<0.05)$, but not for 1989. No significant relationships between water temperature and abundances of other invertebrate taxa occurred.

\section{Diurnal Abundance}

A total of 11 hourly samples were collected during the diurnal sampling. Overall, amphipods were the most abundant macroinvertebrate in the samples (Table III). $\underline{\mathrm{C}}$. salmonis was the most abundant species captured (703) followed by $\underline{\mathrm{C}}$. spinicorne (257), and Ramellogammarus spp. (110). Larval craytish, Pacifasticus spp., trichopterans, and Corbicula manilensis, were also frequently captured.

The abundance of $\underline{\mathrm{C}}$. salmonis varied significantly over time (Figure 10). Catches ranged from a low of $0.8 / 1,000 \mathrm{~m}^{3}$ before dusk to a high of $42.8 / 1,000 \mathrm{~m}^{3}$ just after midnight. The mean catch of $31.0 / 1,000 \mathrm{~m}^{3}$ during darkness was significantly higher $(t=2.61,8$ d.f., $P=$ 0.0312 ) than the mean catch of $12.0 / 1,000 \mathrm{~m}^{3}$ during daylight.

The abundance of $\underline{\mathrm{C}}$. spinicorne over time was less variable (Figure 10) ranging from $3.4 / 1,000 \mathrm{~m}^{3}$ before dusk to $12.3 / 1,000 \mathrm{~m}^{3}$ at about $2200 \mathrm{~h}$. There was no significant difference 


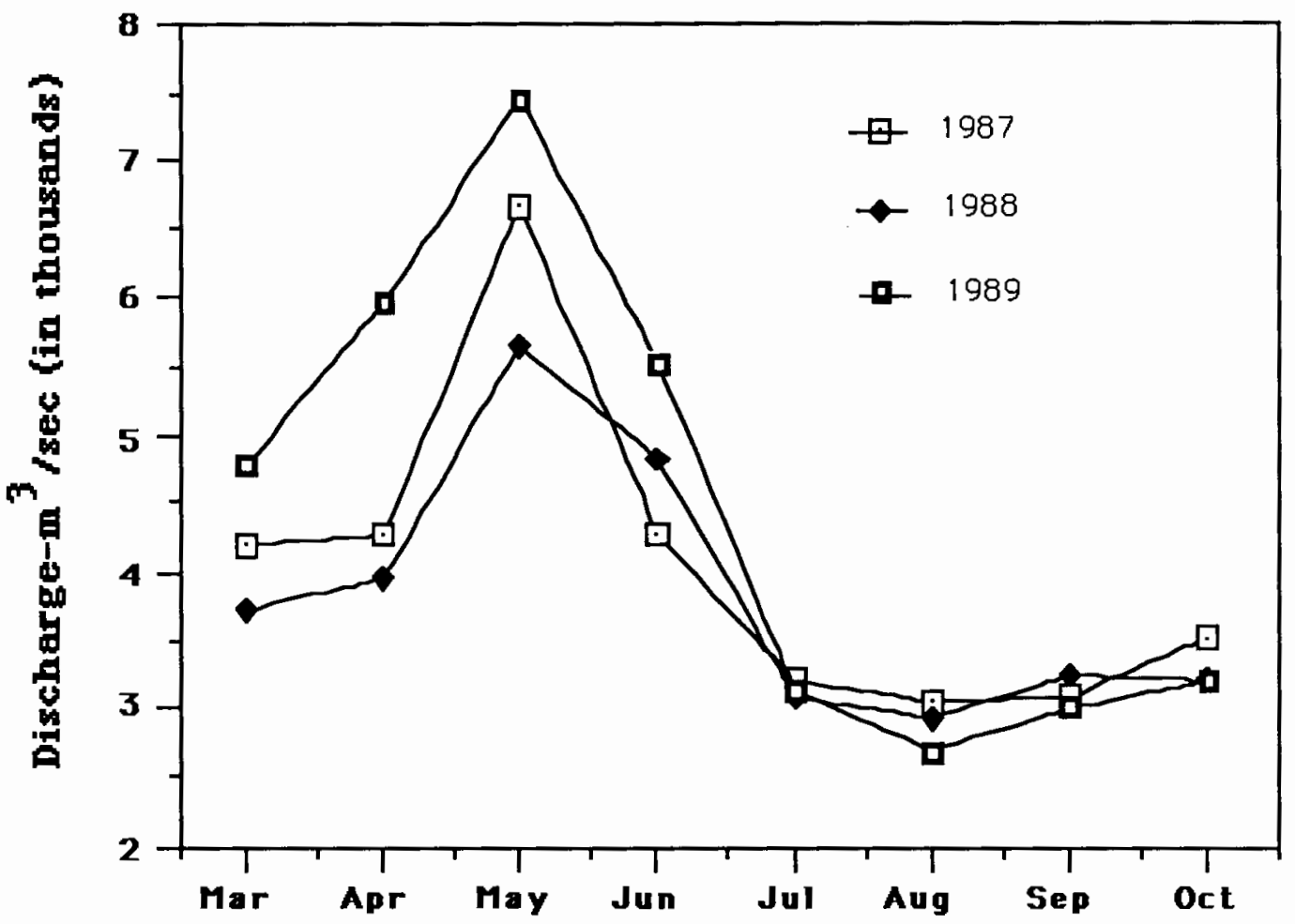

Figure 8. Mean monthly river discharge $\left(\mathrm{m}^{3} / \mathrm{sec}\right.$ in thousands) at Bonneville Dam from March through October, 1987-1989. 


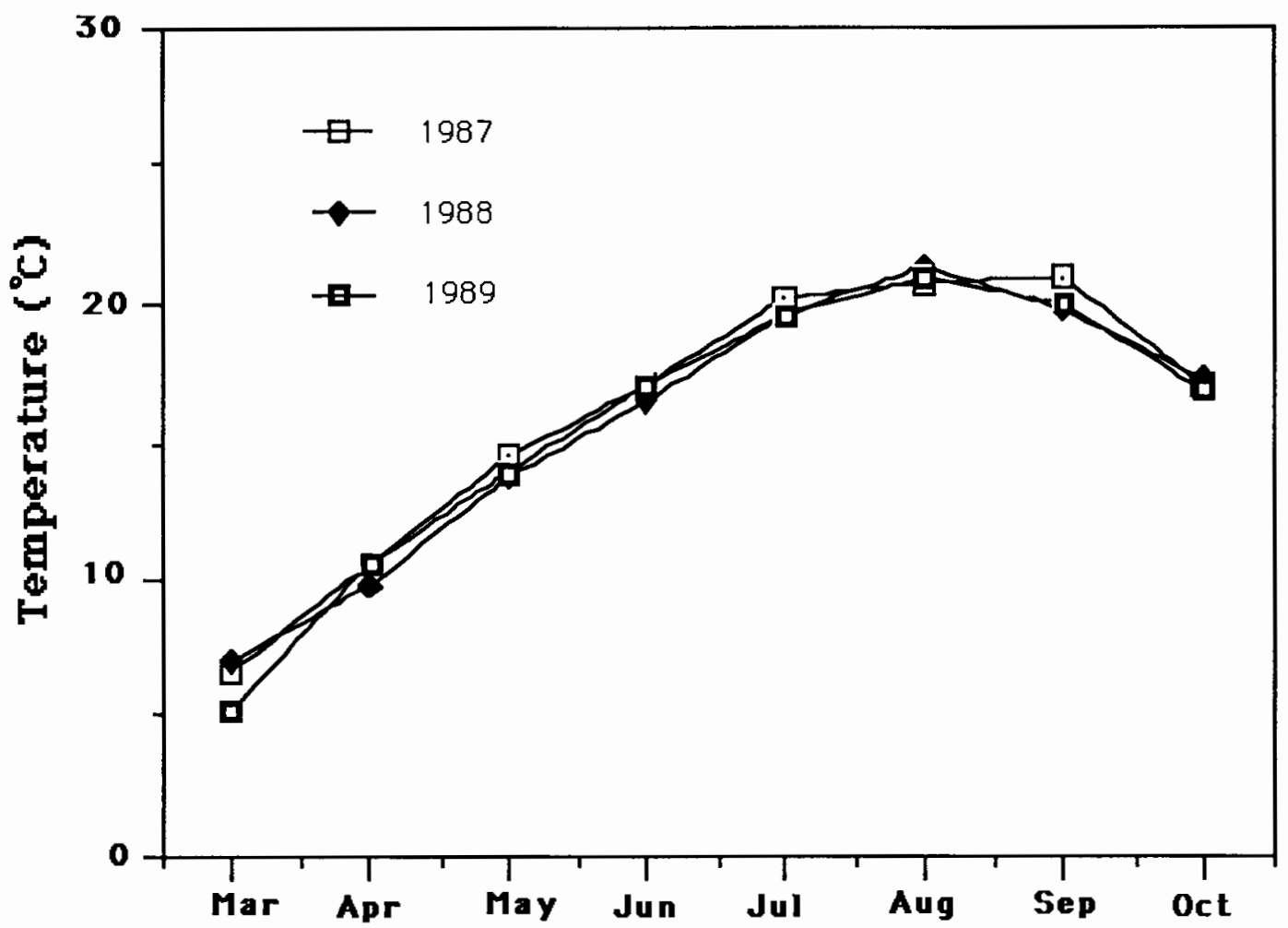

Figure 9. Mean monthly water temperature $\left({ }^{\circ} \mathrm{C}\right)$ at Bonneville Dam from March through October, 1987-1989. 
NUMBERS OF INVERTEBRATES CAPTURED DURING THE 25-26 MAY DIURNAL CONDUCTED AT IVES ISLAND. NUMBERS PRESENTED ARE THE TOTAL FROM ALL HOURS COMBINED UNADJUSTED FOR FLOW.

\begin{tabular}{|c|c|c|}
\hline $\begin{array}{l}\text { Phylum: } \\
\text { Class: }\end{array}$ & $\begin{array}{l}\text { Annelida } \\
\text { Polychaeta } \\
\text { Neanthes limnicola }\end{array}$ & 1 \\
\hline $\begin{array}{l}\text { Phylum: } \\
\text { Class: }\end{array}$ & $\begin{array}{l}\text { Mollusca } \\
\text { Gastropoda } \\
\text { Hydrobiidae } \\
\text { Fisherola }\end{array}$ & $\begin{array}{l}12 \\
29\end{array}$ \\
\hline $\begin{array}{l}\text { Class: } \\
\text { Order: } \\
\text { Famil }\end{array}$ & $\begin{array}{l}\text { Plecypoda } \\
\text { : Heterodonta } \\
\text { ly: Corbiculidae } \\
\text { Corbicula manilensis }\end{array}$ & 124 \\
\hline $\begin{array}{l}\text { Phylum: } \\
\text { Class: } \\
\text { Order: }\end{array}$ & $\begin{array}{l}\text { Arthropoda } \\
\text { Crustacea } \\
\text { Mysidacea } \\
\text { Neomysis mercedis }\end{array}$ & 6 \\
\hline Order: & $\begin{array}{l}\text { Amphipoda } \\
\text { Ramellogammarus spp. } \\
\text { Corophium salmonis } \\
\text { Corophium spinicorne }\end{array}$ & $\begin{array}{l}110 \\
703 \\
257\end{array}$ \\
\hline Order: & $\begin{array}{l}\text { Decapoda } \\
\text { Pacifasticus spp. }\end{array}$ & 101 \\
\hline $\begin{array}{l}\text { Class: } \\
\text { Order: } \\
\text { Order: } \\
\text { Order: } \\
\text { Order: } \\
\text { Order: }\end{array}$ & $\begin{array}{l}\text { Insecta } \\
\text { Ephemeroptera } \\
\text { Trichoptera } \\
\text { Diptera } \\
\text { Coleoptera } \\
\text { Odonata }\end{array}$ & $\begin{array}{r}8 \\
62 \\
2 \\
1 \\
1\end{array}$ \\
\hline Class: & Arachnoidea & 1 \\
\hline
\end{tabular}




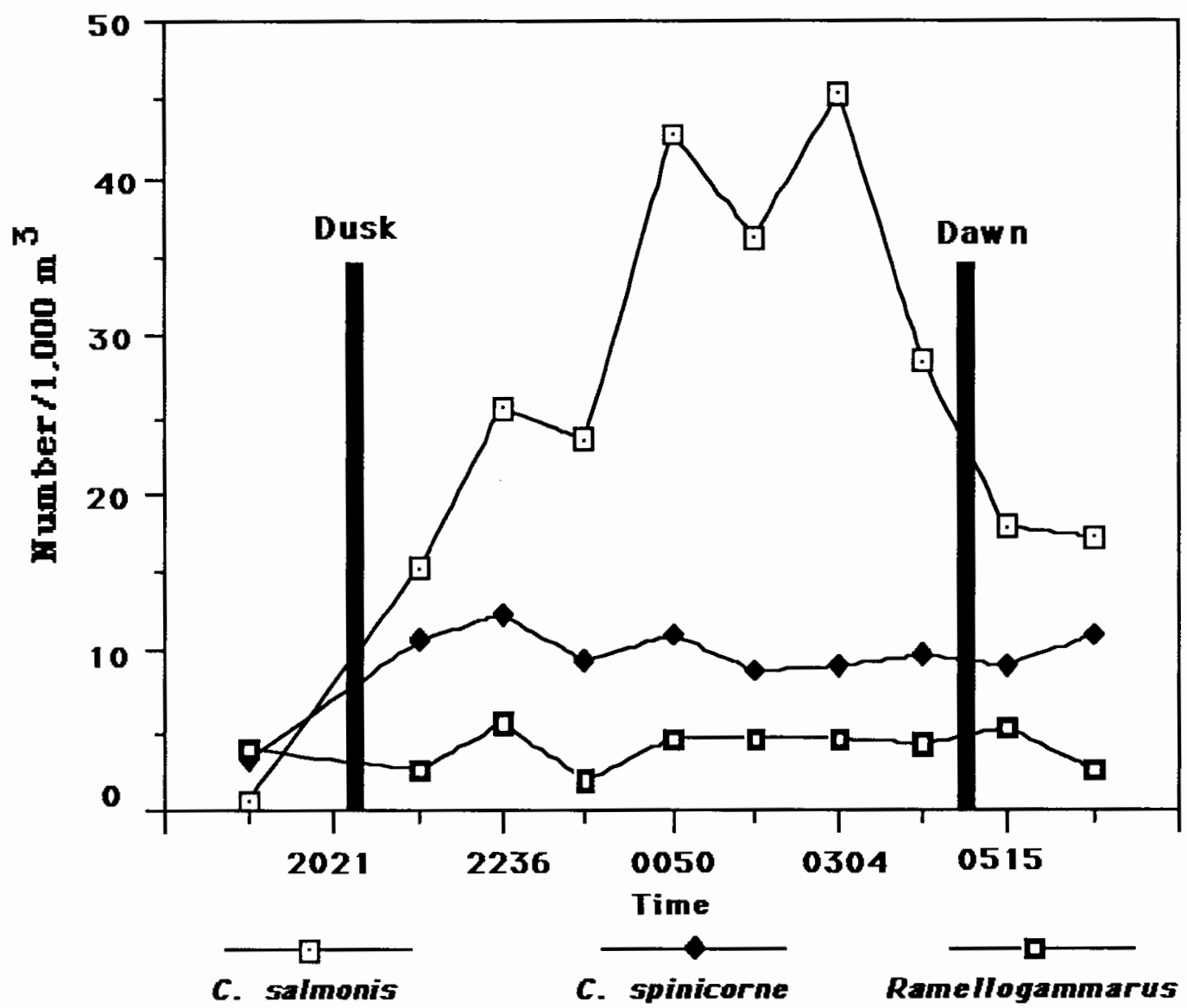

Figure 10. Diurnal variation in amphipod numbers captured at lves Island on 25-26 May, 1987 using a D-ring plankton net fished on the bottom. 
$(t=0.95,8$ d.f., $P=0.4358)$ between the mean catch during darkness $\left(10.2 / 1,000 \mathrm{~m}^{3}\right)$ and during daylight $\left(7.9 / 1,000 \mathrm{~m}^{3}\right)$.

There was also little diurnal variation in the catch of Ramellogammarus spp. ranging from 2.5 to $5.6 / 1,000 \mathrm{~m}^{3}$ (Figure 10). Mean catches during darkness $\left(4.0 / 1,000 \mathrm{~m}^{3}\right.$ ) were nearly the same as during daylight $\left(3.8 / 1,000 \mathrm{~m}^{3}\right)(t=0.24,8$ d.f., $P=0.8162)$. Catches of other invertebrate species were low or inconsistent and were not evaluated.

\section{Yearly Abundance}

Abundance of most major macroinvertebrate taxa in the dritt at Ives Island (April August mean) decreased from 1987 through 1989 (Figure 11). The number of $\underline{\mathrm{C}}$. salmonis decreased significantly $(t=2.98,24.2 \mathrm{df}, \mathrm{P}=0.0065)$ from $9.5 / 1,000 \mathrm{~m}^{3}$ in 1987 to $1.8 / 1,000$ $\mathrm{m}^{3}$ in 1988 . During $1989,0.9 / 1,000 \mathrm{~m}^{3}$ were captured at this site which was again significantly less $(t=3.36,23.5 d f, P=0.0027)$ than 1987 .

The number of $\underline{\mathrm{C}}$. spinicorne averaged $9.0 / 1,000 \mathrm{~m}^{3}$ in $1987,6.5 / 1,000 \mathrm{~m}^{3}$ in 1988 , and $1.7 / 1,000 \mathrm{~m}^{3}$ in 1989 . The 1989 catches were significantly less than both $1987(t=4.40,23.8$ df, $P=0.0002)$ and $1988(t=4.74,30.6 \mathrm{df}, P=0.0000)$ catches.

The number of Ramellogammarus spp. also decreased after 1987 from $7.9 / 1,000 \mathrm{~m}^{3}$ to 4.1 and $4.3 / 1,000 \mathrm{~m}^{3}$ in 1988 and 1989, respectively. However, these decreases were only marginally significant $(t=2.25,28.4 d t, P=0.0327$ and $t=2.12,28.5 d f, P=0.0425$, respectively).

Neomysis mercedis numbers also declined significantly $(t=2.73,23.1 \mathrm{df}, \mathrm{P}=0.0120)$ each year from a high of $4.1 / 1,000 \mathrm{~m}^{3}$ in 1987 to $0.3 / 1,000 \mathrm{~m}^{3}$ in 1989 . There was no up or down trend in the number of Trichoptera captured at Ives Island during the three year period.

\section{Population Characteristics}

Mean length frequencies of $\underline{\mathrm{C}}$. salmonis, $\underline{\mathrm{C}}$. spinicorne, Ramellogammanus spp., and Neomysis mercedis generally decreased each month from spring through summer during all 


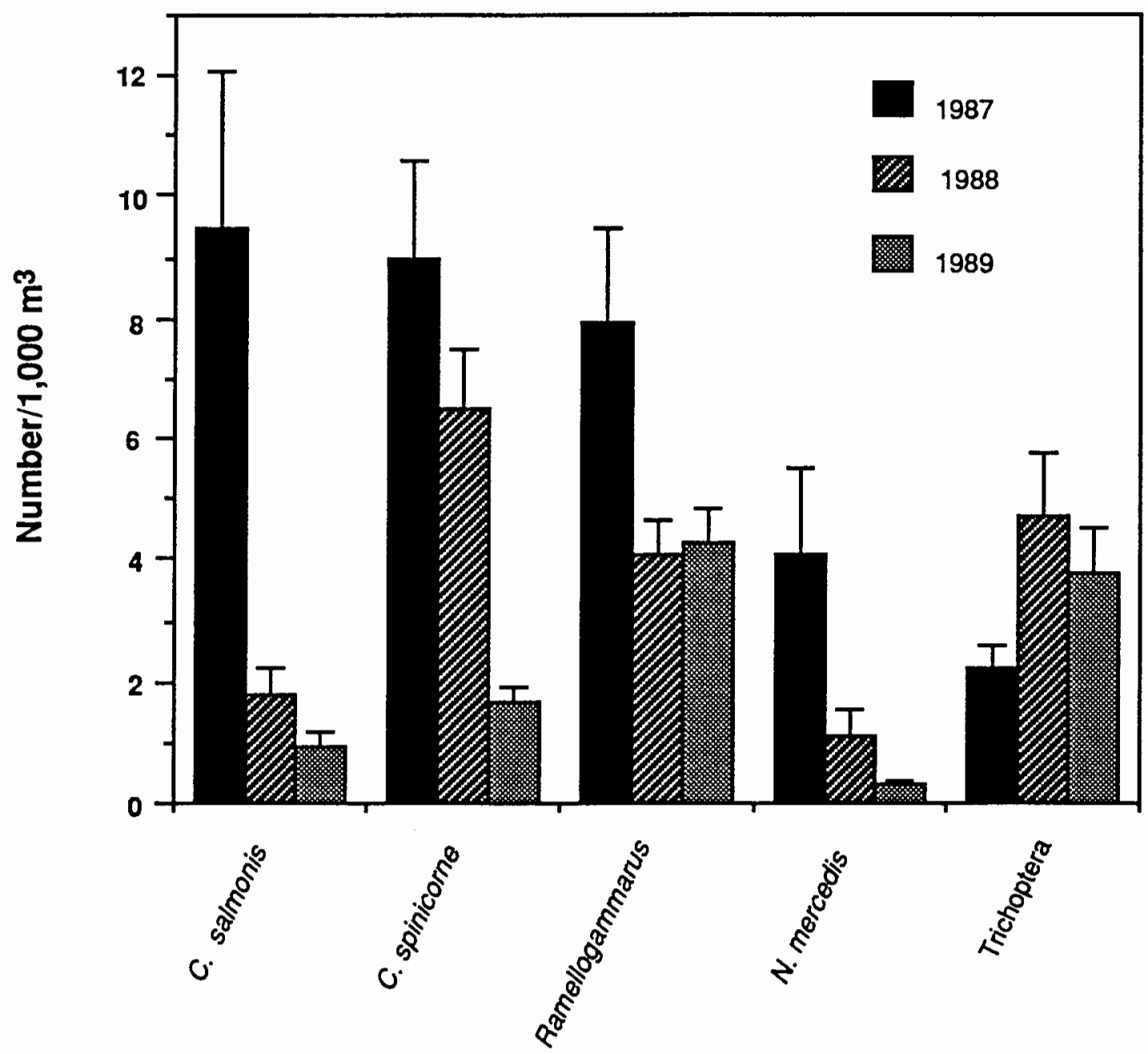

Fiqure 11. Mean annual catch of various macroinvertebrates (ApritAugust) at Ives Island over a three year period, 1987-1989. Error bars represent standard errors. 
three years at Ives Island (Figures $12,13,14$, and 15) probably due to the die-off of older individuals and recruitment of juveniles.

There were also apparent size differences between years. $\underline{C}$. salmonis captured in May and June of 1987 were significantly larger than those captured during corresponding months of $1988(t=3.31,144 d f, P=0.0014$ and $t=2.98,58.4 d f, P=0.0042$, respectively). C. salmonis captured in May and June of 1989 were intermediate in size between 1987 and 1988 (Figure 12).

Size differences between years were also apparent for $\underline{C}$. spinicome (Figure 13). $\underline{\mathrm{C}}$. spinicorne captured in May and June of 1988 were significantly smaller than those captured in May and June of $1987(t=6.87,186 d f, P=0.0000$ and $t=5.64,155 d f, P=0.0000$,

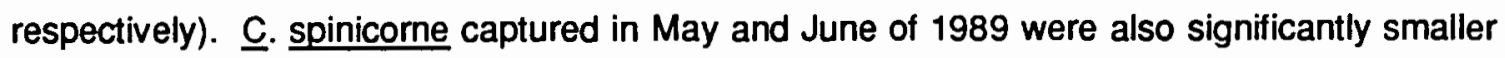
than those captured during May and June of $1987(t=4.52,80 \mathrm{df}, \mathrm{P}=0.0000$ and $t=2.72,79$ df, $P=0.0078$, respectively).

Ramellogammarus spp. were smaller in 1988 (Figure 14), but only significantly smaller $(t=3.08,168 \mathrm{df}, \mathrm{P}=0.0026)$ in June of 1988 than in June of 1989 . Neomysis mercedis were also smaller in 1988 than in 1987 (Figure 15), but not significantly so due to the small numbers captured in 1988.

Over the three years of sampling, sex was determined in $1,151 \underline{\mathrm{C}}$. salmonis of which $63.8 \%$ were males and $36.2 \%$ were females. During the diurnal study conducted in 1988 , enough $\underline{\underline{C}}$ salmonis were captured for a statistical comparison. The proportion of males to females favored males in all of the samples except one (Figure 16). Overall, significantly more males $(68.6 \%)$ than females $(31.3 \%)$ were found $(t=6.43,18 \mathrm{df}, P=0.0000)$.

Conversely, the sex ratio of $\underline{\mathrm{C}}$. spinicorne consistently favored females. Over the three year period, $1,039 \underline{\text { C. }}$ spinicorne were sexed of which $34.5 \%$ were males and $65.5 \%$ were females. During the diurnal sampling, there were significantly fewer males $(39.9 \%)$ than females $(60.1 \%)$ captured (Figure 17$)(t=5.51,18 \mathrm{df}, P=0.0000)$. 


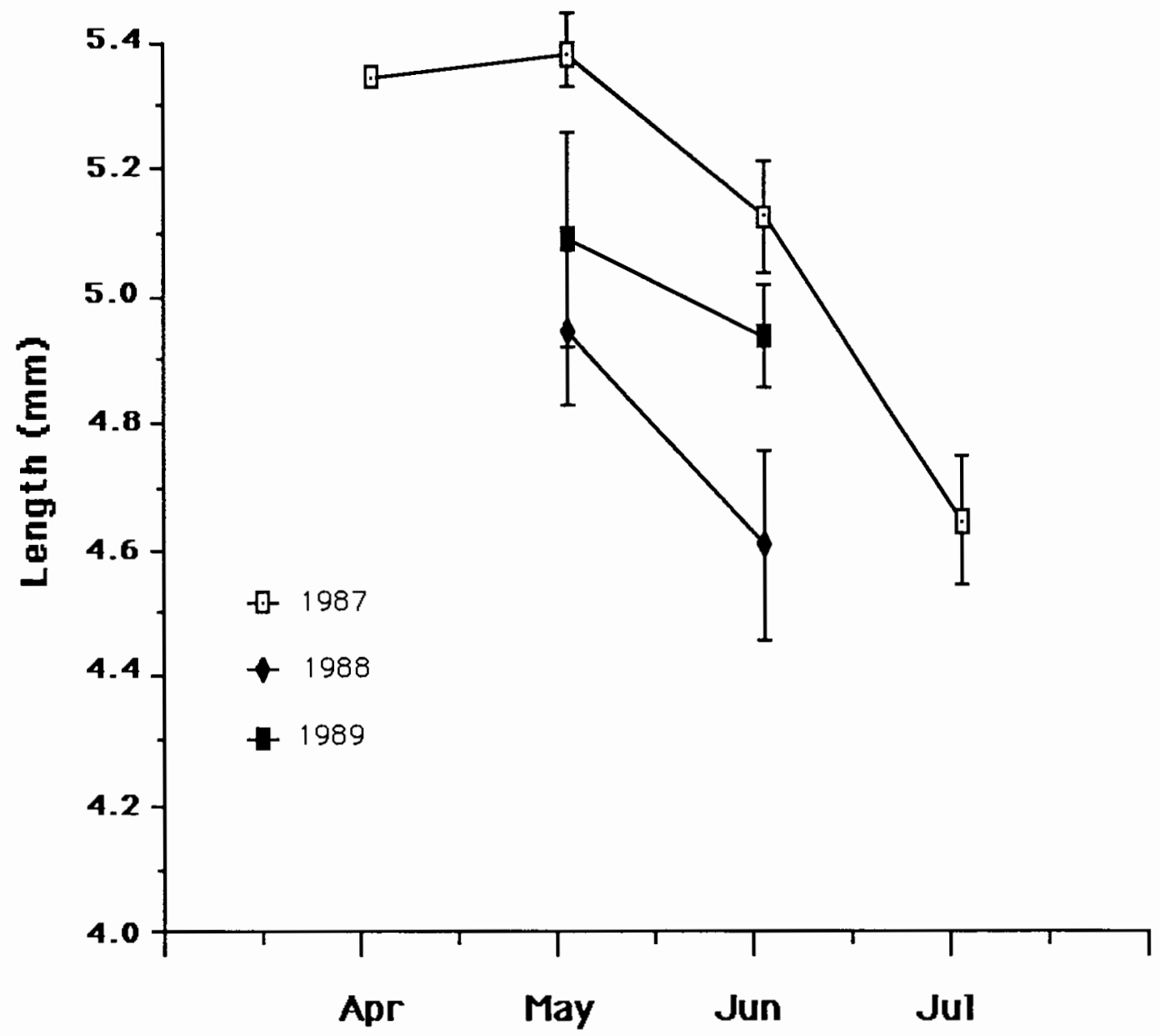

Figure 12. Mean monthly length ( $\mathrm{mm})$ of Corophium salmonis captured at Ives Island over a three year period. Error bars represent standard errors. 


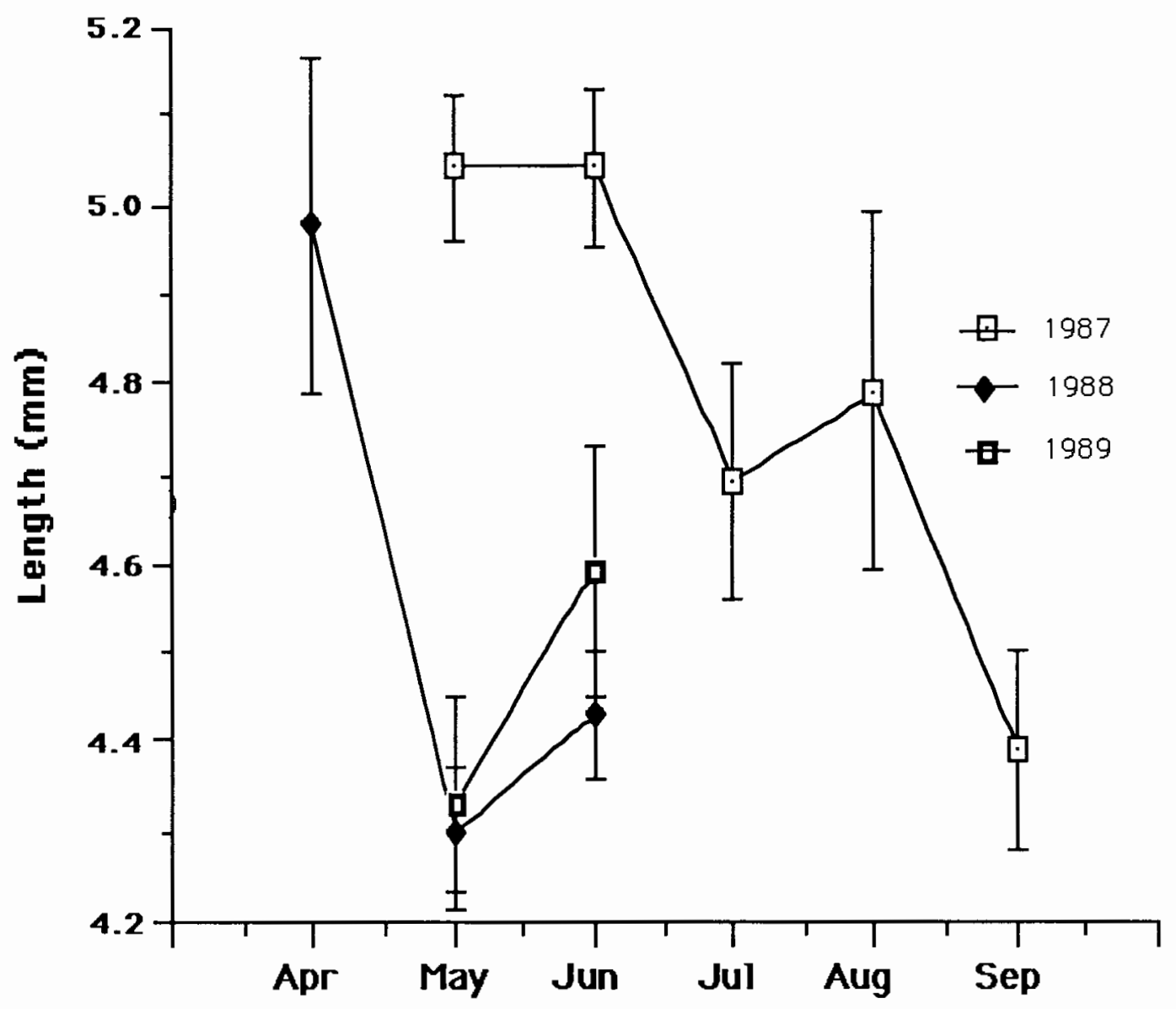

Figure 13. Mean monthly length $(\mathrm{mm})$ of Corophium spinicorne captured at Ives Island over a three year period. Error bars represent standard errors. 


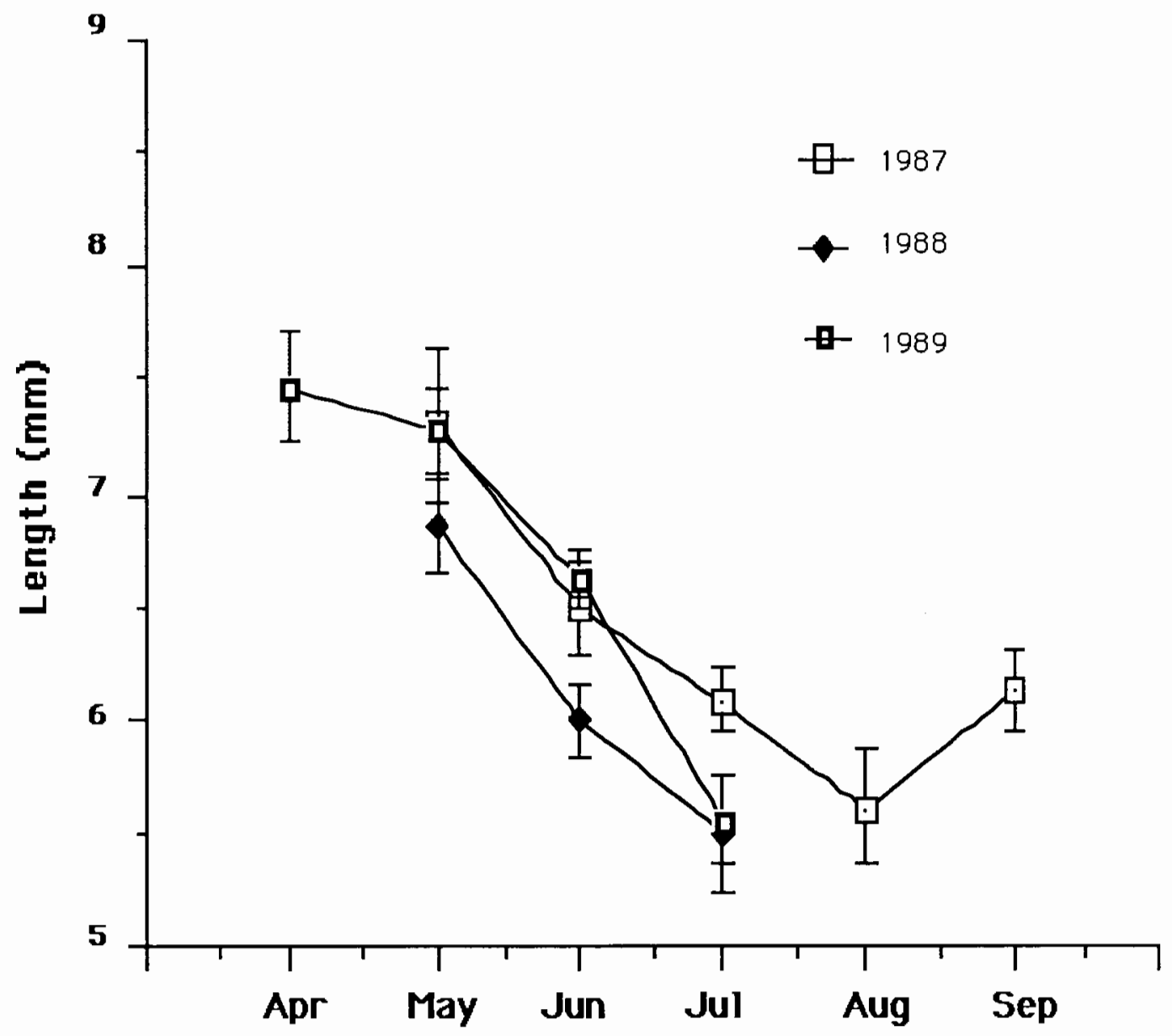

Figure 14. Mean monthly length $(\mathrm{mm})$ of Ramellogammanus spp. captured at Ives Island over a three year period. Error bars represent standard errors. 


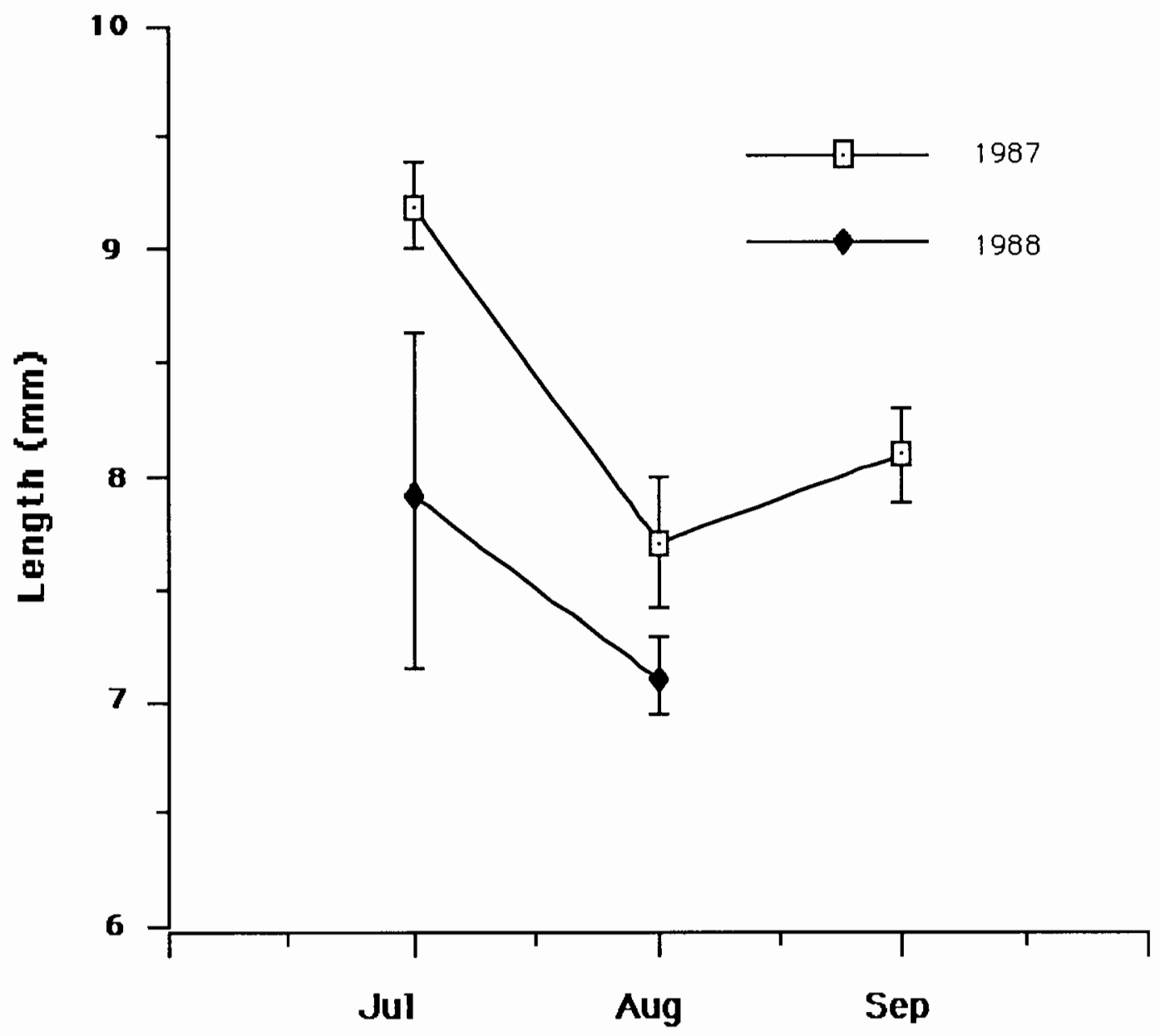

Figure 15. Mean monthly length $(\mathrm{mm})$ of Neomysis mercedis captured at Ives Island over a two year period. Error bars represent standard errors. 


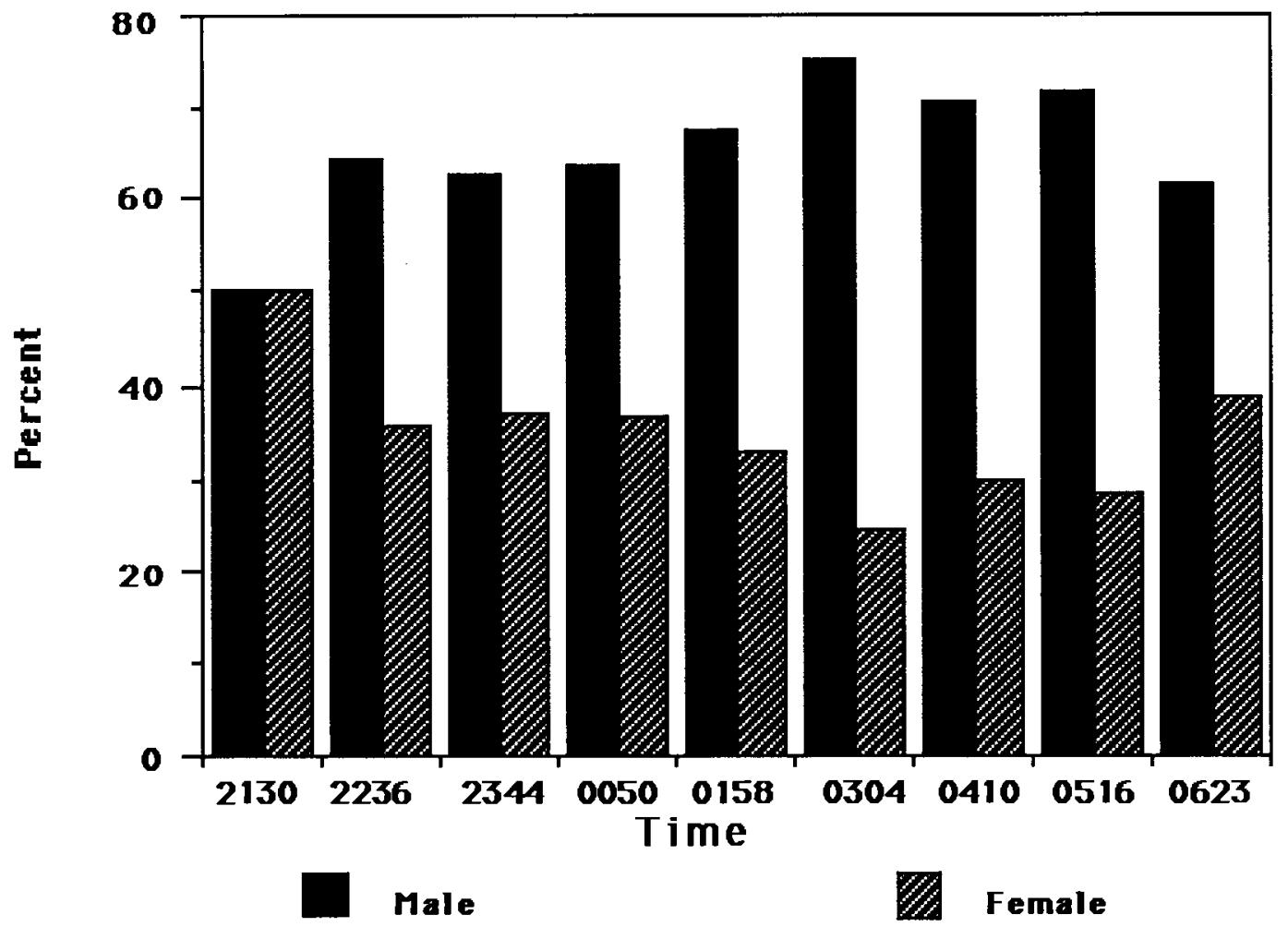

Figure 16. A comparison of Corophium salmonis sex composition (percent of total) captured at Ives Island on 25-26 May, 1987. 


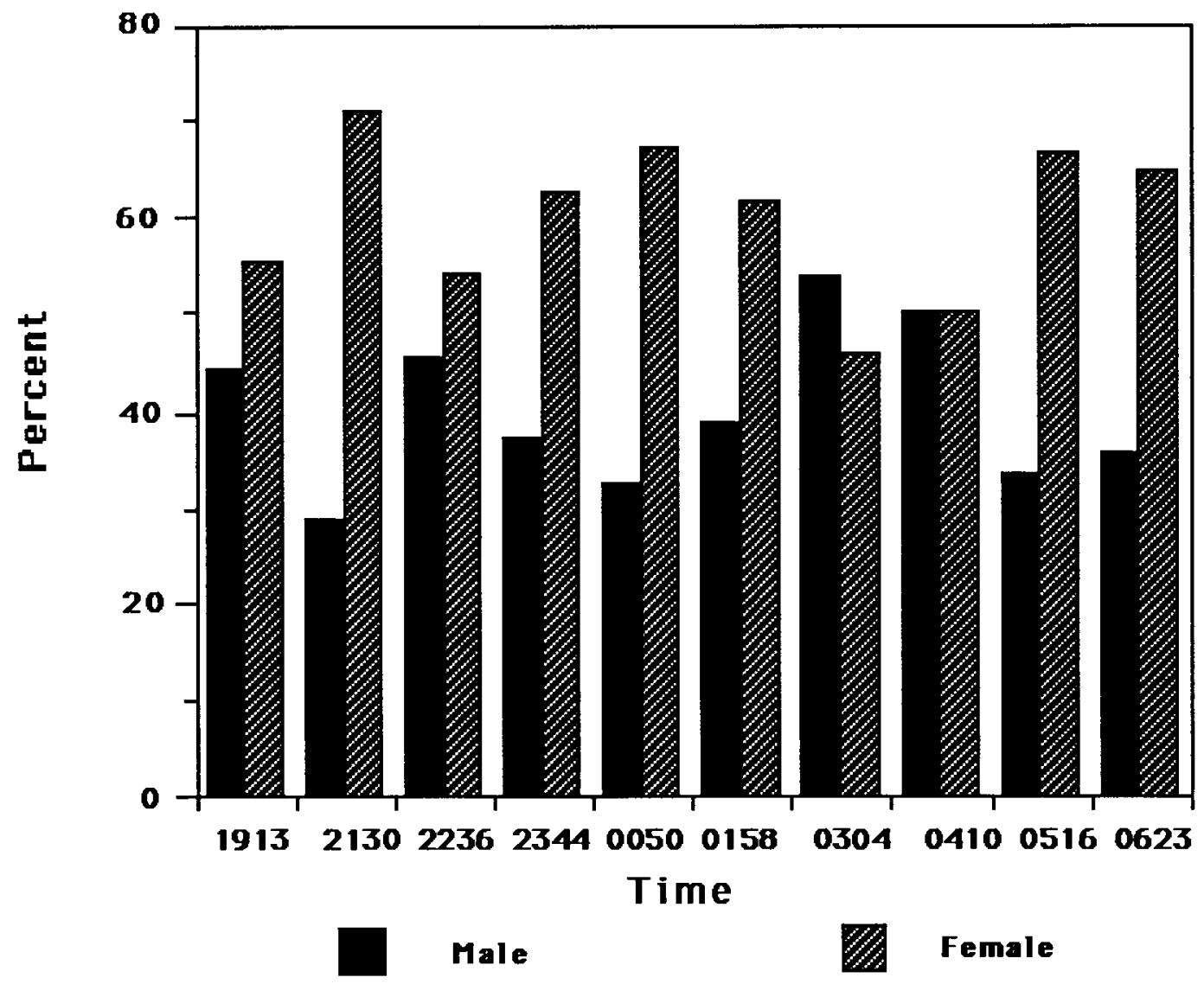

Figure 17. A comparison of Corophium spinicorne sex composition (percent of total) captured at Ives Island on 25-26 May, 1987. 


\section{DISCUSSION}

River impoundment typically results in: 1) altered temperature cycles; 2) modified flow regimes; 3) substrate changes; and 4) increased outflow of fine particulate organic matter (Petts 1984; Ward and Stanford 1979). The magnitude to which these factors are affected by impoundment depends on the physical characteristics of the impoundment; primarily depth, discharge type, and retention time. As a result, macroinvertebrate populations both upstream and downstream of dams are adapted to the suite of conditions caused by these factors (Petts 1984).

This study has demonstrated that the macroinvertebrate drift below Bonneville Dam is sparse and low in diversity. Dominant taxa were amphipod and mollusc species, invertebrates that typically benefit from river impoundment (Petts 1984). The only commonly captured aquatic insects were Trichoptera, primarily Cheumatopsyche spp., a genus of net spinning caddisflies that have also been found to benefit from river impoundment (Petts 1984). Ephemeroptera and Plecoptera are usually reduced or eliminated by dam construction (Petts 1984) and were rarely found in the drift during this study.

Corophium spp. are characterized as brackish water invertebrates that can tolerate freshwater (Green 1968). They are tube-dwelling benthic amphipods which reportedly undergo vertical migrations in the water column, both daily and seasonally, with migrational peaks occurring in the evening hours and during spring (Davis 1978; Higley et al. 1979; Wilson 1983; Hughs 1988). This behavior would increase their predation risk to fish. Several explanations have been proposed to account for this activity. One hypothesis is that drifting may act as a relief mechanism for crowded populations. Corophium spp. populations have highly contagious distributions often reaching densities of over $100,000 / \mathrm{m}^{2}$ (Higley et al. 1984). Dispersal would reduce in-breeding, reduce the risk of local catastrophe, and reduce intraspecific competition. 
Others have associated swimming behavior with reproduction. This hypothesis is supported in some species by observed unequal male/female ratios in the water column (Davis 1978).

The swimming behavior of Corophium spp. has been studied for a variety of species and locations, including field and laboratory studies (see review by Higley et al. 1984). However, all of these studies were conducted in estuarine environments. Hughs (1988), in a field study of $\underline{\mathrm{C}}$. volutator, a widely distributed species (Europe, England, and North American eastern seaboard), found that in an English estuary this species left its burrow to swim from late May to August with semilunar peaks of abundance occurring during the time of the new and full moons. He also found that abundance in the water column had a circadian rhythm; numbers decreased to near zero during the day. He speculated that this species swam at night to avoid predation. Hughs (1988) estimated that 6 to $19 \%$ of the Corophium population swam each night and that all animals swam at least once in their life. Corophium are cryptically colored, which is typical of night active invertebrates; invertebrates that are day active are usually opaque (Robertson and Howard 1978).

In laboratory studies, Morgan (1965) had similar results, but found slightly higher numbers of $\underline{\underline{C}}$. volutator during daytime sampling. Meadows and Reid (1966) found that juveniles of this species had a tendency to burrow and larger animals swam in what they speculated was a search for suitable habitat. A higher proportion of males in the water column have been found in many amphipods, but tube emergence is less common in the parthenogenic species Corophium bonnellii which lends support to the "cruising male" hypothesis (Shillaker and Moore 1987).

Davis (1978) conducted diel plankton tows in Youngs Bay of the Columbia River estuary and found densities of $\underline{\mathrm{C}}$. $\underline{\text { salmonis }}$ as high as $10,000 / 1,000 \mathrm{~m}^{3}$. He also captured $\underline{\mathrm{C}}$. spinicorne, and Eogammarus spp., but in much lower densities. He found that the abundance of all species in the water column increased at night, especially for $\underline{\underline{C}}$ salmonis, which appeared to migrate higher in the water column. Sixty percent of the $\underline{\mathrm{C}}$. salmonis captured in the water column were males, but a majority of females were found when he examined benthic 
samples from this site. For $\underline{C}$. spinicorne, he found that the sex ratios were nearly equal with a slight increase in females near the surface. He also found this species to be more common in daytime samples. Higley et al. (1979) conducted a similar survey in Youngs Bay with similar results, and found that numbers of all species decreased inversely with depth.

The results from this study are remarkably similar to the Youngs Bay studies in the species found, the Corophium sex ratios, and their diurnal behavior. The major differences are the densities (especially for $\underline{\mathrm{C}}$. salmonis) and the age classes found (a higher proportion of juvenile Corophium were found in Youngs Bay than in this study). However, both Youngs Bay studies were conducted in the fall which probably accounts for the different age class structure.

The large difference in reported densities of Corophium in the water column in Youngs Bay (as high as $10,000 / 1,000 \mathrm{~m}^{3}$ ) compared to the numbers found in this study (as high as $42 / 1,000 \mathrm{~m}^{3}$ ) could reflect the animals success in colonizing impoundment habitats. Youngs Bay is a shallow, brackish water embayment with salinities ranging from 0 to about 20 ppt. This type of habitat appears to be ideally suited for Corophium spp. (Higley et al. 1984). Corophium living in freshwater environments of the Columbia River probably experience increased osmotic stress. For $\underline{\mathrm{C}}$. volutator, this stress results in reduced growth and survival (McLusky 1967) and could similarly affect local Corophium spp. Albright and Armstrong (1982) found that sediment size was of greater importance than salinity in determining Corophium population abundance in Grays Harbor, Washington. ‥ salmonis prefers fine sediment while C. spinicome is typically found in courser sediment or areas with structure (Higley et al. 1984). This separation in habitat preference may aid the two species avoid interspecific competition.

Even though the habitat in the vicinity of Bonneville Dam may not support Corophium densities as high as those reported in estuarine environments, Corophium are still the dominant macroinvertebrate species as evidenced by this drift study, benthic surveys conducted in The Dalles pool (Nigro 1990), and by an evaluation of salmonid food habits in this area (Muir and Emmett 1987). Corophium are a vital link between primary production and higher trophic 
levels. When Corophium numbers are reduced, there appears to be few suitable alternative prey species available to the predators that utilize this resource.

On 20 May 1989, 24 spring chinook salmon (Oncorhynchus tshawytscha) stomachs were obtained from fish captured in turbine intakes at Bonneville Dams' Second Powerhouse. The stomach contents revealed that Corophium spp. were still the primary food at this site during this time of year, but had decreased in importance since 1984 (Muir and Emmett 1987).

An examination of sex ratios of Corophium spp. recovered in these salmonid stomachs revealed that $63.5 \%$ of the $\underline{\mathrm{C}}$. salmonis were males and $36.5 \%$ were females. Forty percent of the $\underline{\mathrm{C}}$. spinicorne in the stomachs were females and $60 \%$ were males. These ratios are nearly identical to those found in the drift samples at Ives Island. An examination of sex ratios from $\underline{\mathrm{C}}$. salmonis from benthic samples collected in The Dalles pool $(n=4)$ in 1988 showed that $40.3 \%$ were males and $59.7 \%$ were females; the reverse of that found in salmonid stomachs and the drift. There were also a higher proportion of juveniles in the benthic samples than in either the stomach samples or the drift. These data indicate that salmonids were feeding on the dritt, not the benthos.

Macroinvertebrates that are prey for salmonids in the Bonneville Dam area (primarily Corophium spp.) declined in number and size over the three years of this study. Murtaugh (1989) found in Lake Washington, Washington, that smaller adult female size resulted in reduced fecundity for the mysid Neomysis mercedis and speculated that this was caused by reduced primary productivity. This also appears to be true for Corophium species. Fish and Mills (1979) found a direct linear relationship between length and brood size in $\underline{\mathrm{C}}$. volutator and C. arenarium. At Ives Island during 1988, amphipods were smaller in size and reduced in number compared to 1987; amphipod numbers in the drift in 1989 were even lower. Thus, the reduced numbers and size of Corophium during this study may be a result of lower primary production in the Columbia River during this time.

River discharge during the three years of this study was lower than normal with the lowest flow occurring during 1988, the year when amphipods were smallest. Whether 
increased flows will result in greater amphipod growth and higher fecundity is unknown. Corophium are classified as detritivores, or more specifically as selective deposit feeders, which primarily utilize the adhering diatoms and bacteria that make up the surface film (Higley et al. 1984). Perhaps in low flow years, the amount of allochthonous detritus or nutrients carried downstream is reduced, which could negatively impact Corophium populations.

The type and quantity of prey available to salmonids may directly affect their survival. Rondorf et al. (1985) found that yearling chinook salmon migrating from the upper Columbia River had a $65 \%$ loss in body lipids by the time they reached McNary Dam. In laboratory experiments, they found that starved fish had a similar reduction in body lipids (but less substantial), and this led to decreased survival in seawater challenge tests. Manhken et al. (1982) correlated increased survival of salmonids in saltwater with "critical size" and a "critical growth path".

During early April, there are few macroinvertebrates in the drift available to salmonid smolts. Many salmonid hatcheries currently release their fish during this time period. Researchers have shown that smolts released during this time period are physiologically less prepared to migrate which results in delayed migration and longer residence time in the reservoirs (Giorgi et al. 1990). This occurs during a time period when food resources appear to be limited (this study).

Whether the downward trend in invertebrate abundance observed in this study is part of an oscillating cycle or really a long term trend is unknown. Kirns et al. (1986) found that the importance of Corophium spp. in the diet of subyearling chinook salmon in the lower Columbia River (RKM 75) varied from year to year.

Reservoirs take many years to reach a state of equilibrium (Petts 1984) and the addition of new dams upstream or changes in operation of existing dams can shift that equilibrium. Robeck (1954) found the midchannel areas of Bonneville reservoir are relatively unproductive; the shallower, shoreline areas have much higher invertebrate densities. 
been shown to negatively impact benthic invertebrate populations (Petts 1984). Recent changes in flow management (Fish Passage Center 1989) directed at improving migration conditions for salmonid smolts could be affecting the suite of environmental conditions that these taxa have adapted to.

Besides habitat alterations, the releases of large numbers of hatchery salmonid smolts in recent years could be affecting food abundance. Fish predation has been shown to regulate estuarine amphipod populations; areas where amphipod densities are much higher (Levings and Levy 1977; Nelson 1979). Only long term sampling of macroinvertebrate drift, benthic invertebrate densities, salmonid feeding habits, and primary productivity in the Columbia River will identify the factors controlling macroinvertebrate production and the salmonid resources they support. 


\section{SUMMARY}

1. Macroinvertebrate drift below Bonneville Dam was dominated by amphipod species;

Trichoptera were the only abundant aquatic insects captured.

2. Numbers of macroinvertebrates in the drift declined over the three year period for all major taxa except Trichoptera.

3. All amphipod species were smaller in 1988 than in 1987 which could result in reduced fecundity.

4. Numbers of all taxa in the drift were low in early April when many salmonid hatcheries release their fish; numbers were generally highest in May.

5. Numbers of $\underline{\underline{C}}$. salmonis were significantly positively correlated with flow in all three years. 


\section{RECOMMENDATIONS}

1. Conduct more intensive temporal sampling at several sites to provide information for salmonid hatchery release timing. This would include diel sampling to explore possible lunar effects on macroinvertebrate drift.

2. Expand the sampling effort to include mid-water and surface sampling.

3. Continue the Ives Island study to track year to year changes in abundance and size of macroinvertebrate taxa.

4. Begin long term benthic sampling at selected sites to track changes in macroinvertebrate abundance, size, and fecundity and how these variables are affected by physical factors.

5. Conduct field and laboratory studies on the effects of salmonid feeding success on smoltification and marine survival.

6. Initiate primary productivity studies and correlate these data with river flow and Corophium size and abundance. 


\section{LITERATURE CITED}

Albright, R., and D. Armstrong. 1982. Corophium spp. productivity in Grays Harbor, Washington. Prepared by the Univ. of Wash. and Wash. Dept. of Game for U. S. Army Corps of Engineers Seattle District.

Davis, J. S. 1978. Diel activity of benthic crustaceans in the Columbia River estuary. MS thesis, Oregon State Univ., Corvallis, Oregon.

Chaney, E., and L. E. Perry. 1976. Columbia Basin salmon and steelhead analysis: summ. rep. Pac. Northwest Reg. Comm., 74 p.

Ebel, W. J. 1977. Major passage problems. In E. Schwiebert (editor), Symposium on Columbia River salmon and steelhead. Amer. Fish. Soc., Special Pub., 10:33-39.

Ebel, W. J., C. D. Becker, J. W. Mullan, and H. L. Raymond. 1989. The Columbia River toward a holistic understanding, p. 205-219. In D. P. Dodge (editor) Proceedings of the International Large River Symposium. Can. Spec. Publ. Fish. Aquat. Sci. 106.

Fish, J. D., and A. Mills. 1979. The reproductive biology of Corophium volutator and $\underline{\mathrm{C}}$. arenarium (Crustacea: Amphipoda). J. Mar. Biol. Assoc. U. K., 59:355-368.

Fish Passage Center. 1989. 1988 Fish Passage Managers Annual Report: Columbia Basin Fish and Wildlife Authority, Project 87-127, U.S. Department of Energy, Bonneville Power Administration, Portland, Oregon. 84 p.

Giorgi, A. E., W. D. Muir, W. S. Zaugg, and S. McCutcheon. 1990. Biological manipulation of migration rate: the use of advanced photoperiod to accelerate smoltification in yearling chinook salmon. Annual report to Bonneville Power Administration, Project 88-141, Portland, Oregon. 33p.

Green, J. 1968. The biology of estuarine animals. Univ. of Wash. Press, Seattle, Wash., 401 p. Higley, D. L., J. B. Morgan, and R. L. Holton. 1979. Biological baseline and fluoride effects data for Youngs Bay, Oregon, 1974-1975. Supplemental Final Report to Alumax Pacific Aluminum Corp., 1 Nov. 1973 - 30 May 1975. Suppl. to School of Oceanography, Oregon State Univ., Corvallis, Oregon.

Higley, D. L., R. L. Holton, and D. L. Brooker. 1984. Literature review of the amphipod genus Corophium with emphasis on the two west coast species $\underline{\mathrm{C}}$. salmonis and $\underline{\mathrm{C}}$. spinicorne. Submitted to the U.S. Army Corps of Engineers, Portland District. Dep. of General Science, Oregon State Univ., Corvallis, Oregon. 62 p.

Hughs, R. G. 1988. Dispersal by benthic invertebrates: the in situ swimming behavior of the amphipod Corophium volutator. J. Mar. Biol. Assoc. U. K., 68:565-579.

Kirns, R. A., R. D. Ledgerwood, and A. L. Jensen. 1986. Diet of subyearling chinook salmon (Oncorhynchus tshawytscha) in the Columbia River estuary and changes effected by the 1980 eruption of Mount St. Helens. Northwest Sci., 60(3):191-196. 
Kolak, A. S., and D. W. Rondorf. 1987. Effect of differential gastric evacuation and multispecies prey items on estimates of daily energy intake in juvenile chinook salmon. Envir. Biol. of Fishes, 19(2):131-137.

Levings, C. D., and D. Levy. 1977. A "bugs eye" view of fish predation. In Simenstad, C. A. and Lipovsky, S. J. (Editors), Fish Food Habits Studies: 1st Pacific Northwest Technical Workshop, Proceedings, October 13-15, 1976. Univ. of Wash. Sea Grant, WSG-WO77-2, Seattle, Wash., 147-152.

Manhken, C., E. Prentice, W. Waknitz, G. Monan, C. Simms, and J. Williams. 1982. The application of recent smoltification research to public hatchery releases: an assessment of size/time requirements for Columbia River hatchery coho salmon (Oncorhynchus kisutch). Aquaculture, 28:151-168.

McCabe, G. T. Jr., W. D. Muir, R. L. Emmett, and J. T. Durkin. 1983. Interrelationships between juvenile salmonids and nonsalmonid fish in the Columbia River estuary. U.S. Nat. Mar. Fish. Serv., Fish. Bull., 81:815-826.

McCabe, G. T. Jr., R. L. Emmett, W. D. Muir, and T. H. Blahm. 1986. Utilization of the Columbia River estuary by subyearling chinook salmon. Northwest Sci., 60(2):113-124.

Meadows, P. S., and A. Reid. 1966. The behavior of Corophium volutator (Crustacea: Amphipoda). J. Zool., 150:387-399.

McLusky, D. S. 1967. Some effects of salinity on the survival, molting, and growth of Corophium volutator (Amphipoda). J. Mar. Biol. Assoc. U. K., 47:607-617.

Morgan, E. 1965. The activity rhythm of the amphipod Corophium volutator Pallas and its possible relationship to changes in hydrostatic pressure associated with the tides. J. Anim. Ecol., 34:731-746.

Muir, W. D., and R. L. Emmett. 1987. Food habits of migrating salmonid smolts passing Bonneville Dam in the Columbia River, 1984. Reg. Riv. Res. and Manag., 2:1-10.

Muir, W. D., R. L. Emmett, and R. J. McConnell. 1988. Diet of juvenile and subadult white sturgeon in the Lower Columbia River and its estuary. Calif. Fish and Game, 74(1):4954.

Murtaugh, P. A. 1989. Fecundity of Neomysis mercedis Holmes in Lake Washington (Mysidacea). Crustaceana, 57(2):194-200.

Nelson, W. G. 1979. Experimental studies of selective predation on amphipods: consequences for amphipod distribution and abundance. J. Exp. Mar. Biol. Ecol., 38:225-245.

Nigro, A. A. (editor) 1988. Status and habitat requirements of white sturgeon populations in the Columbia River downstream from McNary Dam. Annual Progress Report, July 1987 March 1988. Prepared for Bonneville Power Administration, Division of Fish and Wildlife, Proj. No. 86-50, Portland, Oregon.

Nigro, A. A. (editor) 1989. Status and habitat requirements of white sturgeon populations in the Columbia River downstream from McNary Dam. Annual Progress Report, April 1988 March 1989. Prepared for Bonneville Power Administration, Division of Fish and Wildlife, Proj. No. 86-50, Portland, Oregon. 
Petts, G. E. 1984. Impounded Rivers. Perspectives for ecological management. Dept. of

Geography, Univ. of Tech., Loughborugh, U. K.

Raymond, H. L. 1979. Effects of dams and impoundments on migrations of juvenile chinook salmon and steelhead from the Snake River, 1966-1975. Trans. Amer. Fish. Soc., 108:505-529.

Robeck, G. G., C. Henderson, and R. C. Palange. 1954. Water quality studies on the Columbia River. Special Report, Dept. of Health, Education, and Welfare, U.S. Public Health Service, Washington, DC.

Robertson, A. I. and R. K. Howard. 1978. Diel trophic interactions between vertically-migrating zooplankton and their fish predators in an eelgrass community. Marine Biology, 48:207213.

Rondorf, D. W., M. S. Dutchuk, A. S. Kolak, and M. L. Gross. 1985. Bioenergetics of juvenile salmon during the spring outmigration. Annual report to Bonneville Power Administration, Project 82-11, Portland, Oregon. 78p.

Rondorf, D. W.,G. A. Gray, and R. B. Fairley. 1990. Feeding ecology of subyearling chinook salmon in riverine and reservoir habitats of the Columbia River. Trans. Amer. Fish. Soc., 119:16-24.

Shillaker, R. O. and P. G. Moore. 1987. Tube emergence behavior in the amphipods Lembos websteri Bates and Corophium bonnellii Milne Edwards. J. Exp. Mar. Biol. Ecol., 111:231-241.

Snedecor, G. W. and W. G. Cochran. 1980. Statistical Methods. lowa State Univ. Press, Ames, lowa, $507 \mathrm{p}$.

Spence, J. A. and H. B. N. Hynes. 1971. Differences in benthos upstream and downstream of an impoundment. J. Fish. Res. Board. Can., 28:35-43.

Ward, J. V. and J. A. Stanford. 1979. Ecological factors controlling stream zoobenthos with emphasis on thermal modification of regulated streams, p. 35-55. In J. V. Ward and J. A. Stanford (editors), The ecology of Regulated Rivers, Penum Pub., Ny. Ny.

Wilson, S. L. 1983. The life history of Corophium salmonis in the Columbia River estuary. MS thesis, Oregon State Univ., Corvallis, Oregon. 